\title{
Pedagogy in the Time of Pandemic: From Localisation to Glocalisation
}

\author{
Robert J. Bonk, Ph.D. ${ }^{1}$ \\ Margarita Kefalaki, Ph.D. ${ }^{2}$ \\ Jürgen Rudolph, Ph.D. ${ }^{3}$ \\ Fotini Diamantidaki, Ph.D. ${ }^{4}$ \\ Carolin Rekar Munro, Ph.D. ${ }^{5}$ \\ Sophie Karanicolas, M.Ed. ${ }^{6}$ \\ Paraskevi Kontoleon, LL.B. (Hons.) ${ }^{7}$ \\ Karl-Heinz Pogner, Ph.D. ${ }^{8}$
}

\begin{abstract}
Pandemic - the global spread of an initially local disease like COVID-19-bluntly forces us to stop. How do we respond in higher education to such stopping? Whether at the government level, for our universities, or in our classrooms, no existing playbook prescribes the pathway for dealing with a global pandemic of this magnitude, even now as we emerge from total lockdown to the potential for a new tomorrow. What we have done at this juncture is to capture anecdotal responses within and across countries that may highlight trends for later consideration. Unlike a globalised response that would adopt one approach internationally, our study considers adaptations for local differences in a glocalised set of responses in an attempt to identify new paradigms that reconceptualise not only

\footnotetext{
${ }^{1}$ Professor of Professional Writing, Director of Professional Writing Programs, Widener University, Chester, PA, USA, email: rjbonk@widener.edu

${ }^{2}$ Founder and President, Communication Institute of Greece, Adjunct Professor and Tutor, Hellenic Open

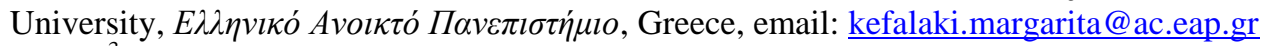

3 Head of Research \& Senior Lecturer, Kaplan Higher Education Singapore, Singapore, email: jurgen.rudolph@kaplan.com

4 Lecturer in Education, University College London, UCL Institute of Education, UK, email: f.diamantidaki@ucl.ac.uk Columbia, Canada, email: Carolin.Rekarmunro@RoyalRoads.ca

6 Associate Professor, Honorary Title Holder, University of Adelaide, Adelaide, Australia, email: sophie.karanicolas@adelaide.edu.au

${ }^{7}$ Lecturer \& Supervising Solicitor, School of Law, University of South Australia, Adelaide, Australia, email: Paraskevi.Kontoleon@unisa.edu.au

${ }^{8}$ Associate Professor, Copenhagen Business School, Department of Management, Society, and Communication, Copenhagen, Denmark, email: kp.msc@cbs.dk
}

5 Professor of Leadership, School of Business, Faculty of Management, Royal Roads University, British
\end{abstract}


teaching and learning, but also assessment. Our responses to the pandemic require leadership_from all of us - to leverage a firm and steady presence, care and compassion for each other, and prudent decision-making. Moreover, identified issues indicate shared threads across the seven institutions of higher education in this research. From a localised perspective emerge responses at the curricular, institutional, and technological levels. First, changes to courses and curricula must respond to emotional needs of students when transitioning from face-to-face (or hybrid) to online delivery; nevertheless, faculty must ensure that academic rigour is not sacrificed in the process. Second, the mission and value of higher education must indicate that institutions will recommit to faculty support beyond emergency remote teaching; furthermore, a sense of campus community needs to be nurtured. Third, the needs of students and faculty must drive the choices of technology - not the reverse-when determining how to transition to online deliveries; in short, administrators must reprioritise factors used in decision-making. Moreover, a glocalised synthesis of responses across all institutions and levels identifies four clustered themes. First, the disruption of the pandemic may lead to innovations in higher education. Second, the role of faculty is becoming redefined beyond content-specific disciplines. Third, educational models must expand to include individuals other than traditional students. Fourth, rigorous pedagogical scholarship, including leadership, will point to new educational insights. Overall, we stand at the crossroads. Rather than being defined by the pandemic, let us seize the opportunity to transform higher education from a paradigm that has been to the paradigm of what might be.

Keywords: Coronavirus; COVID-19; creativity; crisis leadership; digital education; empathy; global education; higher education; independent learners; leadership; learning to learn; online education; pandemic; pedagogy; student-centred. 


\section{Pandemic, Education, and Communication}

Pandemic — the global spread of an initially local disease like COVID-19 — bluntly forces us to stop: to stop traveling, to stop building, to stop congregating, to stop visiting, to stop living as before. Time no longer stretches but rather shatters into before, during, and after the pandemic. Literature can capture this feeling of shattered time, as eloquently prosed in novels by authors such as Gabriel García Márquez in Love in the Time of Cholera and Albert Camus in The Plague. García Márquez's two lovers hoist the yellow flag of cholera to stay isolated from the restrictive world around them, whereas Camus' Doctor Rieux braves an infestation isolating his town in quarantine. What actions do we as educators choose during sequestrations engendered by our "novel" coronavirus? And how meaningfully can we assess the outcomes of our actions?

For this pandemic, compiling datasets of infection rates, border closings, and equipment shortfalls is problematic, as epicentres ebb and flow across the globe. Responses of institutions to the pandemic are more informative, as in the recent analysis by Crawford et al. (2020) that identified similarities as well as differences in pedagogical digitalisation, often influenced by a nation's economy and its proximity to the original outbreak in China. Eventually, records of pedagogies and technologies will be assessed for effectiveness in meeting our challenge, but such analyses require longer timeframes and larger datasets for validity. As this virus continues to play by its own rules, what we can do now is capture anecdotal responses within and across countries waking from lockdown. Together with findings for the "intra-period COVID-19 response" (Crawford et al., 2020), these awakening trends will become guides on this challenging journey for higher education.

This journey, in fact, may be fortuitous. The extension of local responses on a global scale is not necessarily "globalisation" but rather "glocalisation" [as originally coined by geophysicist Lange (see Roudometof, 2015), developed sociologically by Robertson \& White, 2003; expanded economically by Ritzer, 2004; and synthesized by Lange \& Meier, 2009]. The former term refers to the adoption of homogeneity internationally; in contrast, the latter term emphasises adaptation for local differences that constitute a diversified heterogeneity. Consider, for instance, distance education enhanced by technology. Globalisation (in its strictest sense) would result in all/most universities adopting essentially similar approaches internationally. Glocalisation, however, would allow for universities in diverse areas (whether geographically, culturally, etc.) to adapt that model. Moreover, pockets of diversification would cross-pollinate, potentially leading to solutions hitherto unknown. That example illustrates the approach of our research: examining the diverse responses of higher education to the COVID-19 pandemic in an attempt to identify new paradigms from that fecund heterogeneity.

This current article undoubtedly joins others in starting the historical record. Across the globe, each author captures a snapshot of not only pedagogy and technology, but also culture and individuality. 
Understanding why one nation moves education fully online while another places education on hold, as an example, perhaps reflects societal mores as well as computer scarcities. A panoply of schools ranging from state or public systems to private or religious raisons d'être may uncover unexpected motives. Communication technologies that fall prey to robotic intruders might suggest security measures. And even why someone would hack into online educational systems during this time of crisis could reveal a wider vista when grappling with the pandemic's aftermath.

We authors had considerable leeway for topics - associations, institutions, programs, curricula, and courses. After all, factors that may be critical in one situation may be tangential in another. Timing relative to 11 March 2020, the date when the World Health Organization (WHO) officially declared the pandemic, certainly matters. [As much as possible, dates have been specified for time-sensitive information. The evolving nature of the pandemic - including responses by institutions of higher education-rendered full synchronisation problematic.] Nonetheless, we authors shared a common outline for capturing our local situations:

- Overview of higher education at pandemic onset

- Sociocultural, geopolitical, and other influences

- Reflective insight on local response to pandemic

Taken together, such snapshots of selected pedagogical adaptations may indeed reveal parameters for a global paradigm shift in higher education. For each institution's section, an introductory theme offers institution-specific context; these themes are then joined in the overall analysis for the article. May history thus record that we educators harnessed this pandemic's challenges as an impetus for innovation, comprehension, and glocalization.

\section{Impact of COVID-19 on Higher Education}

The following subsections capture snapshots of responses to the pandemic from seven different institutions of higher education from seven different nations across the globe. Table 1 compiles selected responses at the curricular, institutional, and technological levels; Figure 1 exemplifies visually the response of these institutions to the pandemic. 


\section{Table 1. Localised trends in responses of higher education to the COVID-19 pandemic}

\begin{tabular}{|c|c|c|c|c|}
\hline \multirow{2}{*}{$\begin{array}{l}\text { Nation / } \\
\text { Institution }\end{array}$} & \multirow{2}{*}{$\begin{array}{l}\text { Thematic Topic Explored by } \\
\text { Nation / Institution }\end{array}$} & \multicolumn{3}{|c|}{ Localised Trends in Responses of Higher Education to the Pandemic } \\
\hline & & Curricular Level & Institutional Level & Technological Level \\
\hline Singapore / & f higher education in & Affected students $\mathrm{p}$ & Sustained ins & Continued il \\
\hline Higher Education & the knowledge-based economy & alternative learning to earn credit & learning for knowledge economy & in the post-crisis environment \\
\hline Greece / & Technological transitions for & Total transfer to digital requires & Planned online pedagogies vs. & Opportunity for teachers to learn \\
\hline Hellenic Open University & adult student professionals & adjustment for students' needs & emergency remote teaching & new communication technology \\
\hline Australia / & Reimagining the virtual delivery of & Low student confidence requires & Need for educators to delve into & Adaptability requires expertise \\
\hline University of South Australia & an interactive education & pedagogies of constructive care & scholarship of learning/teaching & beyond own discipline/practice \\
\hline United States / & Experiential community projects & Virtual tailoring of projects for & Recommitment to mission and & Synchronous vs. asynchronous \\
\hline Widener University & supported by open education & experiential civic engagement & values for community outreach & provision of academic support \\
\hline United Kingdom / & Imagination and collaborative & Live sessions to discuss project & Imagination and collaboration by & Platforms to connect students by \\
\hline University College London & co-creation by shared interests & ideas and share personal interests & virtually shared personal interest & "remote, not distant learning" \\
\hline Denmark / & Transforming higher education into & Problem-based (group) projects & Bildung (empowered resilience) & Online supervising/counseling, \\
\hline Copenhagen Business School & a community of practice & reflective of practitioner rigour & as pedagogy before technology & internal group work, and exams \\
\hline Canada / & Galvanising leadership of change & Breakdown in mental health that & Loss of community: residencies, & Basic infrastructure for online \\
\hline Royal Roads University & with empathy in unknown future & impedes focused class presence & research, jobs, convocation, etc. & connectivity across time zones \\
\hline
\end{tabular}




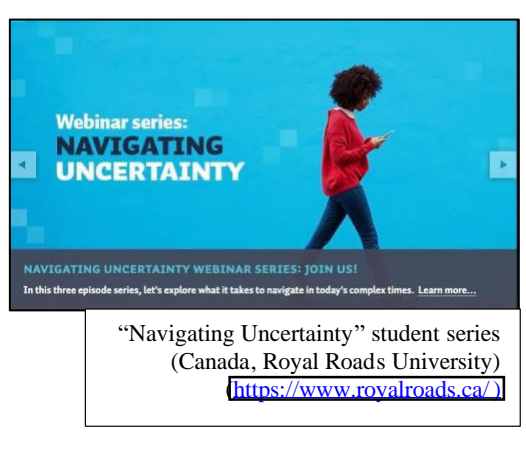

Visual learning environment webpage (Australia, University of So
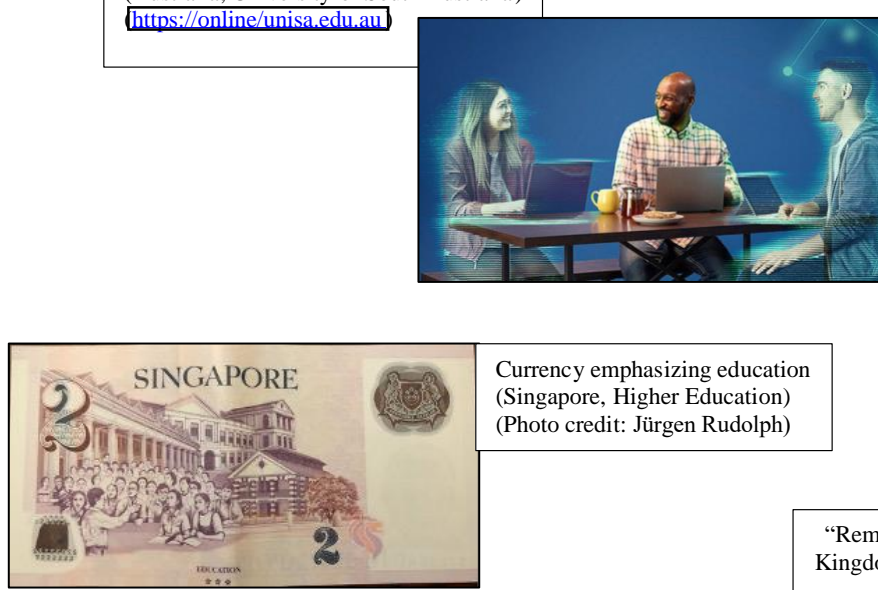

Currency emphasizing education (Singapore, $\mathrm{H}$ (Photo credit: Jürgen Rudolph)

"Remote, Not Distant" theme (United Kingdom, University College London)
https://www.ucl.ac.uk $/ 1$
Practice decisions by choice (Denmark, Copenhagen

School of Business) hittps://studentlife.cbs.dk/
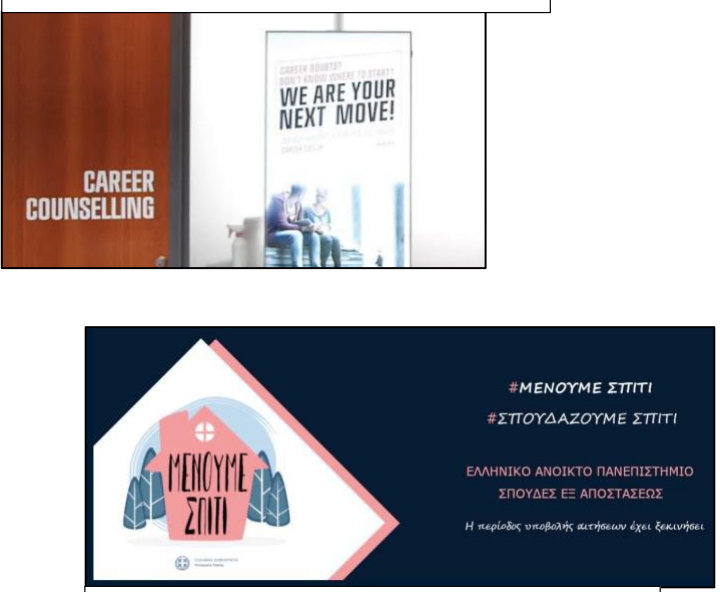

"Stay Home, Study at Home" website logo

(Greece, Hellenic Open University) (Ministry of Health tps://www.eap.gr/el///

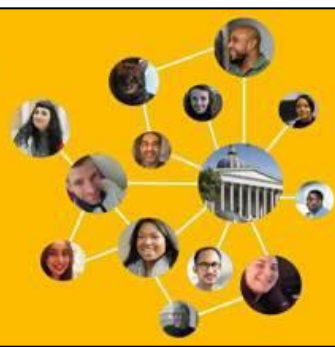

Figure 1. Institutional snapshots for localised responses of higher education to the COVID-19 pandemic 


\section{Higher Education in Singapore (Jürgen Rudolph)}

\section{Prioritizing higher education within the knowledge-based economy: \\ Currency highlights societal value of education (Figure 1)}

\section{Overview of higher education at pandemic onset}

Singapore's "higher education" scene features local Autonomous Universities (AUs) as well as international universities that have either set up their own campuses or deliver their transnational education through Private Education Institutions (PEIs) in a variety of ways (Sam, 2017; Shukaitis, 2018) - ranging between the two extremes of exclusive use of fly-in faculty and a model in which $100 \%$ of the faculty are locally recruited as adjuncts. PEIs are not permitted to offer their own proprietary undergraduate and postgraduate degrees; transnational and proprietary programmes (typically Certificate and Diploma programmes) are under regulatory supervision of the Committee of Private Education - a government agency under SkillsFuture Singapore (SSG). At the time of writing, there are six AUs and 297 PEIs in Singapore (SkillsFuture Singapore, 2020).

Singapore's Global Schoolhouse project was started in 2003 with the aim of attracting world-class universities (Economic Review Committee, 2003; Garrett, 2005; Ng \& Tan, 2010; Waring, 2014; Ye, 2016; Lo, 2017). Initially, the Global Schoolhouse project was dominated by research-intensive American institutions (e.g., Johns Hopkins University and Chicago Graduate School of Business; Sidhu et al., 2011). Wharton Business School was contracted to provide expertise in setting up Singapore's third AU, Singapore Management University (SMU; Sidhu et al., 2011), and MIT collaborated with the Singapore University of Technology and Design (SUTD) in its first seven years (Singapore University of Technology and Design, 2020). International diversification led to a less America-centric model with the inauguration of transnational campuses, for instance by INSEAD (a highly ranked French business school) and the Indian Jain School of Management (Sidhu et al., 2011). Singapore's Global Schoolhouse project has been substantially modified through the years - also as a result of Singaporeans' concerns of foreigners competing with them for university places and jobs (and local tax payers subsidising their foreign competitors' university education) - with the likely result of an even more vibrant and highly competitive education hub (Waring, 2014).

\section{Sociocultural, geopolitical, and other influences}

As early as a decade ago, Singapore was already characterised as one of the highly developed knowledge economies (Margison, 2011). Singapore has a population of 5.7 million, an economy worth US\$ 503 billion, and a per capita income of more than S\$ 89,000 (up from US\$ 511 in 1965), which places the Republic within the ten wealthiest countries globally (Waring et al., 2019; 
Department of Statistics Singapore, 2020). This city-state also boasts a multicultural population (with an ethnic Chinese majority and large minorities of Malays and Indians, amongst many other ethnic groups), a garden city environment, as well as regional hubs for next to everything. The reasons for Singapore's economic success are multi-layered and complex, but, to some extent, it can be credited to the government's persistent investments in education. High participation in tertiary education can be attributed to both Confucian values (Margison, 2011) and the Singapore government's continuing emphasis and support of lifelong learning in the knowledge economy. The Singapore government's focus on education can be gleaned by looking at the Singapore two-dollar note, which features a classroom setting with the single word "Education".

\section{Reflective insight on local response to pandemic}

In the first quarter of 2020, the city-state's use of public-health best practices (built on experience from the SARS outbreak in 2003) had garnered praise from WHO (Seet, 2020). The relative success of the Singapore government's early response to the COVID-19 pandemic could be attributed to factors such as fast deployment of testing; rigorous, technology-informed contact tracing; real-time integrated tracking and analytics; availability of expert medical care; and an efficiently imposed system of quarantine orders, stay-at-home notices, and leaves of absence (Craven et al., 2020; Singapore Ministry of Health, 2020; Crawford et al., 2020).

However, in April 2020, the rate of new infections increased alarmingly, and some of the international media that previously cited Singapore's coronavirus response as the gold standard changed their tune and called the city-state disenchanted and Southeast Asia's new epicentre (Fahrion, 2020; Ehrhard \& Fähnders, 2020). The fact that more than 300,000 foreign low-wage workers from the construction industry reside in multi-bed rooms in 43 privately run, multi-storey dormitories (that resemble container villages) has turned out to be a major weak point in the fight against the pandemic in Singapore (Hein, 2020; Ehrhard \& Fähnders, 2020; Heng, 2020). The Singapore government has certainly recognised the seriousness of the situation. In addition to extending the "circuit breaker" (lockdown-type restrictions during which residents are advised to stay at home as much as possible) to 1 June 2020, medical staff are now stationed at all dormitories; the number of tests has been increased significantly; social distancing rules are enforced more stringently; and many workers have been relocated to vacant apartments, floating hostels, and military barracks (Ehrhard \& Fähnders, 2020).

Initially, Singapore's education system did not witness measures quite as drastic as some other countries: Universities and schools were not closed-with some institutions of higher learning teaching fully online, while others pursued blended learning approaches (Crawford et al., 2020). Graduation ceremonies and other large-scale events had been postponed throughout, and overseas placements (including internships and exchange programs) as well as inter-university and other 
external activities were all suspended (Channel News Asia, 2020a; Singapore Ministry of Health, 2020; Crawford et al., 2020). Affected students had been provided with alternative, credit-bearing educational arrangements such as online learning, and Singapore's Ministry of Education asked students in local AUs and polytechnics to return from their official overseas placements as soon as possible (Ang, 2020a). Face-to-face classes were supported by online strategies, leveraging the EdTech boom of recent years. Singapore's universities use web-conferencing platforms such as Zoom, BlackBoard Collaborate, Webinar, and Panopto, partially as contingency measures and partially integrated into their learning management systems (Crawford et al., 2020).

With the new, stricter "circuit breaker" measures that were implemented in early April, schools and universities were compelled to switch to home-based learning between 8 April to 4 May (and later extended to 1 June). Universities responded by conducting all lessons online and by converting their exams into a variety of online formats or into take-home assignments (Ang, 2020b). For instance, Nanyang Technological University (NTU) cancelled all undergraduate on-campus exams, quizzes, and tests during the circuit-breaker period, while all other forms of assessments such as projects, reports, essays, presentations, and assignments were to continue and be submitted online (Ang, 2020b). For modules in which in-person continual assessments and exams were cancelled, grades were to be computed based on each student's existing scores (Ang, 2020b). In addition, both NTU and the National University of Singapore (NUS) have begun to allow students to take more modules on an ungraded basis, providing a satisfactory/unsatisfactory (S/U) option that does not affect their grade-point average (Mahmud, 2020).

It remains to be seen whether the current move to online delivery will be merely an event-driven adoption or whether educators will continue to use additional technological tools for innovative andragogical practices in a post-crisis environment. It is, however, crucial to differentiate wellplanned online learning from courses offered online in response to a pandemic such as COVID-19 (Hodges et al., 2020). The speed at which the move to online occurred in Singapore and many other countries was astounding and unprecedented. Despite research evidence to the contrary, online learning has been often stigmatised as being of lower quality as compared with face-to-face learning (Hodges et al., 2020). Rather than falling prey to this misperception of online learning as a weak option and mistaking current emergency measures with the real McCoy (which usually requires much more extensive preparation), the current emergency measures should perhaps be evaluated as what they are: Emergency Remote Teaching (ERT) (Hodges et al., 2020). Nevertheless, variations in the designation of "faculty" (from fly-in to land-bound and in-between) may prompt other institutions in other nations to revisit their expectations of the traditional faculty role. 


\section{Hellenic Open University, Greece (Margarita K. Kefalaki)}

\section{Easing the technological transition for adult student professionals: \\ Website logo encourages flexible study at home (Figure 1)}

\section{Overview of higher education at pandemic onset}

Contributing to the historical record of this global alert situation during the COVID-19 impact, this section provides a snapshot of professional and personal experiences in the educational environment of Greece (Hellada). Specifically, this section speaks of the way that the university at which I have taught (since 2011), the Hellenic Open University (HOU), has dealt with the rushed educational changes that the global health emergency of COVID-19 imposed.

HOU, founded in 1992 and officially established in 1997, is the only public university in Greece to adopt and operate the model of distance education all around Greece since its foundation. With central offices in Patras and various university branches all over Greece (Athens, Ioannina, Crete, Thessaloniki, Patras, Larisa, Komotini, Hania, just to name some), its purpose is to facilitate the participation of people around Greece. This public higher education institution has students who pay their own tuition fees. HOU offers 48 programs, with the participation of 40,695 students, of which 23,989 are Master's students and 16,706 are graduate students. But how was HOU affected by our uninvited and unwelcomed coronavirus?

Greece, with a population of just over 11 million, had (as of 13 April), 2,145 confirmed cases of coronavirus and 99 fatalities, far lower than elsewhere in Europe ${ }^{9}$ (Smith, 2020). Nevertheless, the closure of all educational units at all levels of our country on 10 March (one day before WHO declared the pandemic) highlighted the need and importance of $100 \%$ technologically supported remote teaching (e-learning). HOU (educators, personnel, students) already had a demonstrated and long-standing experience in distance education. Still, some courses (five per year) also involved face-to-face interaction. The fact that, due to the pandemic, all these face-to-face courses had to turn immediately into online courses did not cause special problems.

\footnotetext{
${ }^{9}$ Helena Smith (2020) gives an answer to how the Greek government's quick reaction protected the country's population from a health crisis: "In late February, before Greece had recorded its first death, carnival parades were cancelled. On 4 March, before most of Europe, schools were ordered closed. Within days, bars, cafes, restaurants, nightclubs, gyms, malls, cinemas, retail stores, museums and archaeological sites were also shuttered."
} 
The combination of off-campus and on-campus education (blended learning or hybrid learning, including synchronous and asynchronous communication) in HOU permits students to attend a classroom in a traditional room of teaching and complete their assignments back at home (asynchronous communication). The quality of academic work is always maintained at a high level, controlled by a form of constant evaluation from the students and a group of educators responsible for the application and assessment of the learning model in the departments that they support. Communication and interaction between the professor/counselor and the students in our university take place mainly through a Learning Management System based on the Moodle platform. ${ }^{10}$ This platform provides the possibility of modern or asynchronous teaching and the deposit of educational material (printed educational material, audiovisual material, questionnaires, quizzes, activities, assignments, etc.). Students can also submit their work and obtain feedback, commentary, and grading by their professor/counselor (Alachiotis et al., 2019).

\section{Sociocultural, geopolitical, and other influences}

Being the professor/counselor of one of the Athens departments (Athens-3), I teach the Master's

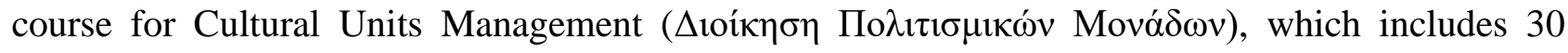
adult students of various educational ${ }^{11}$ and working backgrounds. ${ }^{12}$ After 10 March, all previous face-to-face meetings were transferred to virtual formats, using Skype for Business. ${ }^{13}$ These adult students (typically with their own families and of course different responsibilities and needs from a typical teenage student) often require more time and assistance with concurrently learning course content and digital technology. Hence, institutions with similar student populations should expect an effort-intensive transition from face-to-face meetings to digital learning.

However, adults who engage in education beyond traditional schooling and into lifelong learning offer a very important study opportunity of their societal contributions: ensuring the availability and competence of the labour force by extending working life, raising the employment rate, improving productivity, providing educational opportunities for the entire adult population, strengthening social cohesion and equality, and alleviating effects of the recession (Euricide, 2018). Nevertheless,

\footnotetext{
${ }^{10}$ For more learning tools, it is interesting to visit Top Tools for Learning (https://www.toptools4learning.com/), where the 200 most-used methods of learning in the field of education (personal, professional, higher education) for 2019 are presented-results of the 13th Annual Learning Tools Survey published 18 September 2019.

${ }^{11}$ Two of them already have a Master's degree, and one of them has also a Ph.D.

12 Advocates, educators, public agents, social media specialists, marketing specialists, philologists, teachers, media professionals.

${ }^{13}$ To name some online educational system possibilities used during this time of crisis, we could speak of Skype for Business (https://www.skype.com/en/business/) and Big Blue Button (bigbluebutton.org), which are also used by HOU, and of course Zoom (https://zoom.us/), GoToMeeting (https://www.gotomeeting.com/), and Jitsi Meet

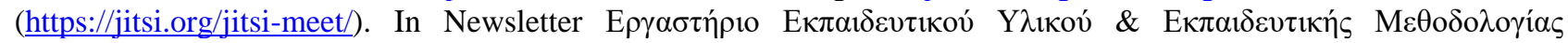

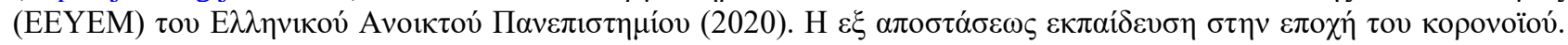

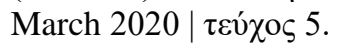


I believe that the younger generation is much more familiar with new technologies and so can more easily adapt to technological "innovations".

As already stated, in response to concern over COVID-19 spreading in Greece, HOU had already migrated absolutely all courses to online mode as of 10 March (the day that WHO declared the COVID-19 pandemic). Everything was in place for our first totally synchronous remote course to be delivered with the help of Skype for Business on 14 March. [Of course, the fact that I speak about adult students (30-70 years old) has had a major impact on how quickly they accept and can respond to changes, especially having to do with technological innovations.]

There was a generally positive response from most of my students; nevertheless, there were cases of students who experienced some slight difficulty in adapting, which is not surprising. Despite some reluctance and uncertainty (judging by emails that I received before the online meeting), the course went extremely well, and the participants seemed to have the inner need to communicate and exchange, even in a digital environment. Students, no matter their age or background, need special support and follow-up from the educator, especially when face-to-face interaction is interrupted. Collectively, we as students and educators need to feel part of a community with common purposes, methods, and actions. All need to interact and not feel alone - no matter how hard a situation might be. But this sense of shared community is not the only prerequisite to online education.

Nowadays, more than ever, with the actual global condition of closure of everything, the need arises for innovative approaches to distance education, along with staff training, to maximize conditions, benefits, and opportunities offered by distance education. Educators should also be educated about remote modes of teaching; in turn, universities should formulate ways of constant evaluation and amelioration of their resources (human and technical). The COVID-19 pandemic has changed the running of programmes in higher education, and nearly all universities are now using an online system to deliver remaining parts of the program.

\section{Reflective insight on local response to pandemic}

The COVID-19 pandemic will have a significant effect on higher education, as distance education undoubtedly will be expanded. More universities around the world will have to adapt (obtain the needed techniques and technology, train educators, hire and train staff, obtain the right educational resources). In any disruptive period, educators who see the positive side can engage in the outcomes of what is actually being experienced. This huge health crisis can be viewed as an opportunity to widen perspectives. Facilitating that learning, new ways of training and education will be offered and adopted. Teachers and personnel must educate themselves in order to adapt and adjust to new ways of education and communication. 
The fact that all kinds of institutions and universities have urgently moved their classes online in response to the COVID-19 health crisis might engage serious risks. Open-access learning requires a well-planned online process. The rapidity with which some institutions were obliged to make this change might yet come at the expense of the quality of the offered learning experience:

In contrast to experiences that are planned from the beginning and designed to be online, ${ }^{14}$ emergency remote teaching (ERT) is a temporary shift of instructional delivery to an alternate delivery mode due to crisis circumstances (Hodges et al., 2020, n.p.).

Institutions like HOU that already had some aspects of e-learning or blended elements in their curricula find it much easier to make the transition to fully online programmes than those who are launching online teaching from scratch. The advantages offered by online education-even under this urgent occasion of hurried moves to online forms - can only be "protected" by recognising that effective online instruction has nothing or little to do with what most of the institutions are actually offering, which Hodges et al. (2020, n.p.) aptly names "emergency remote teaching (ERT)". Being offered quickly to cover the basic needs of communicating with students, this type of teaching cannot, in many cases, represent the well-prepared online course.

\section{University of South Australia, Adelaide}

(Sophie Karanicolas and Paraskevi Kontoleon)

Reimagining the virtual delivery of an interactive education:

Technology facilitates an interpersonal milieu (Figure 1)

\section{Overview of higher education at pandemic onset}

At the start of 2020, the idea that the COVID-19 pandemic would have a profound impact on higher education in Australia-let alone our University of South Australia (UniSA)—-seemed ludicrous. The city of Adelaide lies on the southern coastline, seemingly isolated like the rest of the continent. UniSA, however, conducts research on a global scale, with international students representing about one-sixth of its nearly 34,000 students (UniSA, 2020a). UniSA also "respectfully acknowledge[s] the Kaurna, Bunganditj and Bangarla First Nations Peoples and their Elders past and present, who are the First Nations' traditional owners of the land of University of South Australia's campuses in Adelaide, Mount Gambier and Whyalla” (UniSA, 2020b). The Law School especially prides itself

\footnotetext{
${ }^{14}$ For information on higher institutions that offer distance education all around the world, one can take a look at the European Association of Distance Teaching Universities, https://eadtu.eu/, and web portals like www.studyportals.com

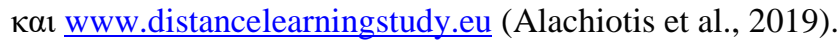


on its "practical learning experiences including mooting, negotiation, [and] witness examination" (UniSA, 2020b). COVID-19 would soon be challenging that notion of legal education.

As for the nation, on 20 March 2020, the Australian Government announced the border closure of Australia to all travelers, except for Australian citizens and residents (and their immediate family members) who were returning home. State border closures, except for essential or compassionate travel, soon followed. All incoming passengers, whether international or interstate, were subject to a mandatory 14-day isolation period. On 22 March, Prime Minister Scott Morrison announced the closure of all pubs, clubs, hotels, places of worship, gyms, sporting venues, cinemas, and casinos. As in the rest of the world, people were required to remain home at all times except for travel to work or for essential services. Families were distanced: Visits to other households and to aged-care facilities where many parents resided were totally banned in the Eastern states. The Australian Government had clear social distancing requirements of 1.5 metres at all times.

Regarding education, schools remained open strictly to cater for the children of essential frontline workers; children of parents considered non-essential workers were asked to stay home and engage in distance learning. Just like that - parents became full-time teachers, and teachers were expected to develop online teaching skills overnight. University campuses, unlike primary and high schools, were shut immediately. Teaching staff were asked to conduct classes fully online, without any notice. Domestic and international students alike were now isolated and often without employment, as their main employers were all in the service industries.

By 25 March, the Prime Minister announced formation of the National COVID-19 Coordination Commission (NCCC) to develop a coordinated national approach to both the public health and social management of the pandemic. Together with Australia's Chief Medical Officer, NCCC developed an evidence-based response to the management of all health aspects associated with the pandemic. Further formed was the National Cabinet, comprising the premiers of every state of Australia along with the territory chief ministers. Australia was quick to react and implemented strict measures despite low rates of COVID-19 infections when compared against global standards. According to the COVID-19 Worldometer site, Australia had recorded 6,927 cases and 97 deaths, with 6,124 recovered cases, as of 9 May (2020). Australia truly is the lucky country. Its geographic isolation and wide living spaces facilitated containment of the virus. 


\section{Sociocultural, geopolitical, and other influences}

The "luck" of geographic isolation has not shielded Australia from the pandemic's effects on higher education in general or on UniSA in particular. An email circulated by UniSA President and Vice Chancellor David Lloyd on the evening of 1 February confirmed the university's implementation of recommendations to prohibit travel to China (Australian Health Protection Principal Committee, 2020) and ordered staff and students returning from China to self-isolate for 14 days. This email raised some alarm bells, but in truth most thought that the virus could not possibly affect Australia in any meaningful way. A further email on 5 February confirmed that the university had only a small number of staff and students affected by travel from China. We were safe from COVID-19. Or so we thought.

Additionally, the COVID-19 pandemic has exacerbated issues with governance in the Australian higher education sector. The World University Rankings reported that Australia's policy to "shift the cost of higher education on to students who now won't be able to get jobs or travel to study is the real crisis here" (Jayasuriya, 2020). So how did UniSA respond to this crisis? The very idea of closing national and state borders, cancelling international and interstate travel, and converting to online teaching seemed like an alternate universe. How wrong we were.

Wind the clock forward to mid-March and, within just weeks, the gravity of the situation hit home for the School of Law. On the morning of 16 March, the Dean of Law circulated an email advising staff that the School was pre-empting the possibility that teaching might soon be online. The next day, the Vice Chancellor sent an email advising staff and students that all face-to-face teaching would be converted to fully online delivery within the week, and that the university campus would remain closed to all staff and students until further notice. This switch has engendered the greatest challenge for many colleagues: reimagining legal education in a virtual environment that had served up to that point as a mere repository of learning and reading resources.

\section{Reflective insight on local response to pandemic}

Not all higher education teachers have experience with interactive online learning. I had never used Zoom before COVID-19; however, I had been fortunate enough to have had a personal interest in the scholarship of online learning prior to the pandemic. ${ }^{15}$ For the majority, the reality of having to change mostly traditional teaching practices overnight to fully online delivery meant that teachers who had spent months preparing face-to-face courses now were swimming in unchartered territory. The overwhelming demand for the use of online teaching platforms such as Zoom in the School of Law meant that, in addition to the obvious anxieties of changing to online delivery, we also had IT issues rendering it almost impossible to get through a virtual classroom without disruption.

\footnotetext{
${ }^{15}$ Reflective insight told from the perspective of co-contributor Paraskevi Kontoleon.
} 
I recall receiving that email on the morning of 17 March. In fairness, I welcomed the decision. After all, I live with and care for my mother, who suffers from Alzheimer's Disease; the thought of her contracting and possibly dying from the virus was enough motivation for me. Whilst the conversion from face-to-face to online teaching has been challenging, I have found that it has forced me to engage further with teaching pedagogies, to look at ways in which I can provide better support to students, and, funnily enough, to help me get to know my students better.

Currently, I am teaching a class of 150 first-year students. In our first Zoom meeting, fear amongst the student cohort was obvious. Most already lacked confidence in their abilities to get through their first year of university; the impact of COVID-19 meant a further blow to their confidence. Turning to teaching pedagogies for help, I have found that a pedagogy of care (Motta and Bennet, 2018) and a strong focus on constructive alignment (Karanicolas, 2018) have been my saving graces in this new COVID-19 world.

How have I done this? I have made a point of regularly contacting students (cohorts or individuals) via email; setting virtual meetings with classes, small groups, and individuals; developing succinct and clear audio and video lecture material with embedded quizzes; providing follow-up emails with feedback; and developing videos to further explain difficult concepts as well as to answer students' concerns about assessments.

How do I know this has worked? I have kept the students informed, empowering them to provide feedback on the benefits of these resources and approaches, along with how they may be improved. Feedback from students indicates that $90 \%$ have found these teaching approaches beneficial to their education - they have felt supported and motivated to continue learning.

Whilst the pandemic has been difficult and challenging, its change has helped me to develop better teaching materials for students that will help improve their learning experience when we eventually return to face-to-face teaching. Change has also highlighted the need for educators to delve into the scholarship of learning and teaching. To have expertise in only your discipline of practice does not provide the flexibility and the adaptability that will be required of an educator in this new world in which we find ourselves teaching. 


\section{Widener University, Chester, Pennsylvania, United States (Robert J. Bonk)}

\section{Focusing on experiential community engagement through open education: Course projects adapt for topic, teams, and technology (Figure 1)}

\section{Overview of higher education at pandemic onset}

The pandemic's evolution within the United States has been and remains problematic. Across fifty states encompassing a large swath of the North America continent, the virus spreads geographically as well as numerically. Moreover, the governors of these states retain jurisdiction over most-if not all - of their internal responses: when to close and open areas for education, commerce, recreation, and so on; where to position first-responders and available resources; what employment positions and skills are deemed essential; who implements, monitors, and assesses data for peaks and lulls; and how to negotiate with other states' governors as well as the federal government. ${ }^{16}$ Agencies within the federal system, notably the Centers for Disease Control and Prevention (CDC, 2020a) and the National Institute of Allergy and Infectious Diseases (NIAID, 2020), play complementary roles, as do institutions of higher learning, notably the Johns Hopkins University (JHU) School of Medicine, whose Coronavirus Resource Center (2020a) has held an internationally respected position during the pandemic. The CDC also issued guidelines for administrators of higher education institutions (CDC, 2020b).

The first reported case of COVID-19 in the United States occurred in Washington State (on the Pacific side of the country) in January 2020 (CDC, 2020c). In Pennsylvania (on the Atlantic side), Governor Tom Wolf declared a disaster emergency due to COVID-19 on 6 March (Wolf, 2020a), with stay-at-home orders for the counties near Philadelphia (which included Widener University's Delaware County). The order's enforcement officially commenced on 23 March for a two-week period ending 6 April; that period was subsequently extended until 8 May and effective for all 67 counties within the Commonwealth of Pennsylvania (Wolf, 2020b). A three-phase reopening plan, based on predetermined metrics, was announced on 25 April (Wolf, 2020c). Tentatively, the first state counties could begin opening as early as 8 May. (The county containing Widener University, though, is in the last region expected to open.)

In response to concern over COVID-19 spreading in Pennsylvania, Widener University decided, as did several other local institutions, to migrate absolutely all courses to online mode as of 19 March (one week after WHO declared the pandemic). Only "life-sustaining personnel" retained campus

\footnotetext{
${ }^{16}$ An examination of the disarray of the federal response in the United States is well beyond the scope of this article. Undoubtedly, the response of the Trump administration (ranging from denial and contradiction to aggrandizement and polemics) will be fodder for tell-all books, pseudo-news shows, and late-night parodies.
} 
access after 21 March. Because many courses used traditional methods, faculty were allowed an extra week to prepare for the transition to fully online mode. This switch would remain through the remainder of the spring semester; courses for the summer and fall sessions are to be considered relative to the pandemic's status (Widener University, 2020a).

\section{Sociocultural, geopolitical, and other influences}

Widener University, a private institution in the eastern United States, comprises a central campus in Chester, Pennsylvania, for undergraduate and graduate students, as well as two nearby campuses for its law schools. As of 2019, the approximately 6,500 students had an enrolment ratio of 3:2:1 for undergraduate, graduate, and law, respectively. Despite its relatively small size, this university offers over 40 undergraduate programs and over 50 graduate and professional programs. Widener University's student body encompasses 22 countries; nearly a third of students are minority and/or international citizens (Widener University, 2020b).

Originally, Widener University operated as a military college. That foundation remains influential in its mission and vision: "Widener is a dynamic, inclusive academic community, transforming students into scholars, leaders, and globally engaged citizens...by creating a learning environment where curricula are connected to societal issues through civic engagement". At all levels of study, students are encouraged to participate in formal courses and informal activities that immerse them into the community. For Widener, that "community" ranges from study abroad and global trips to experiential projects within the surrounding area of Chester (Widener University, 2020b).

As for Chester itself, demographic parameters paint a different picture from the university. For a population of approximately 34,000 residents, the poverty rate in Chester is $35.9 \%$. Four out of five self-identify as Black, African-American, Hispanic, or Latino. Although nine out of ten have health coverage, about one-third rely on Medicaid, the governmental system intended for those of financial need. Homicide (6.92 per 100,000) poses one of Chester's greatest health risks (Data USA, 2020). The city's rate of coronavirus infection on 9 April was $0.08 \%$ of its total population (Delaware County Coronavirus COVID-2019, 2020).

If the coronavirus has an upside, that might be its ability to expose the underlying societal inequities within the United States. Non-governmental agencies (NGOs), such as the Health Equity Initiative (HEI) in New York City, continue efforts at ameliorating inequities within the country's health and social systems (HEI, 2020). Anecdotally, community groups report alarming trends in COVID-19 rates for testing, confirmed cases, and deaths. Substantiation remains stymied because not all states release breakdowns by race or ethnicity: 2/50 for testing, 41/50 for confirmed cases, and 38/50 for deaths, as of 30 April (JHU 2020b).

Given Chester's profile, differential effects of COVID-19 by race or ethnicity need scrutiny. Even a quick examination (as of 30 April) suggests differences between areas (total populations) known to 
be unbalanced by race or ethnicity. Delaware County (which contains Chester) has a higher fatality rate at 6.19 than does Pennsylvania overall (more homogenous) at 5.13 (JHU 2020c). ${ }^{17}$ Widener University's investment into the Chester community, evidenced by its Office of Civic Engagement (Widener University 2020c), may potentially address such inequities. Initiatives across institutions, as offered by PHENND (Philadelphia Higher Education Network for Neighborhood Development) and Pennsylvania Campus Compact, undoubtedly will be instrumental as well.

\section{Reflective insight on local response to pandemic}

Amongst the many courses offered at Widener University are those in professional writing, which typically include community-based experiential projects (Bonk, 2013). Although relatively small in the overall scheme of the institution, this program already offered hybrid versions of undergraduate courses, as well as an online graduate course in healthcare writing. All of the undergraduate courses continue to use the open-access texts that had been curated in the previous two years. An electronic (but not open-access) text for the graduate class had already been made available by the publisher. All these students had access to a customized website for providing online writing support, a critical need in a communication-driven world (Bonk, 2019). A librarian was added to class rosters within the Canvas (https://www.instructure.com/canvas/) learning management system.

Class assignments were easily adapted for a fully online delivery. The entry-level class adjusted its experiential project into a team proposal to use social media to foster a sense of campus community despite their isolation. Mid-level classes, which did not have specific community projects, migrated to a fully online platform that simulates modern business. Healthcare professionals in the graduate class, already pushed to personal limits, used an optional blog to share healthcare updates, trade coping techniques, and express human emotions. On an individual basis, deadlines for assignments were delayed so that these front-line professionals had time for home and family. Several students expressed gratitude for such latitude extended to them during the pandemic.

As suggested by these loosely representative courses, the switch from in-person or hybrid to virtual depends on myriad factors for pedagogical success. The entry-level class, as an example, benefited from analysing how pandemic updates could be disseminated without inundating email accounts; in the process, they discovered even more about the coronavirus. In contrast, the graduate class needed to step away from pandemic-related assignments; most selected topics from their own careers but saved the optional blog for catharsis.

Extending educational opportunities to the wider community similarly must remain cognizant of local situations. Open-access tutorials on writing, for instance, have been intentionally designed for the Chester Education Foundation (CEF) using the LOOC (Localized Open On-line Content) model

\footnotetext{
${ }^{17}$ Case fatality rates calculated from data as of 30 April 2020.
} 
(Bonk, 2016). Although not a project during the current timeframe, a previous class collaborated with an accessibility officer on teaching adjustments for students with special needs or functional disabilities. In a survey of U.S. colleges/universities admitting students with special needs, 70\% used technological adaptations (Raue \& Lewis, 2011) —a level requiring further attention.

Pressure from the pandemic, though, has relegated many responses to the ERT (Emergency Remote Teaching) mode (Hodges et al., 2020). But these "disruptive" pressures can be viewed as teaching opportunities. Developed by Clayton M. Christensen in 1997 for management science, disruption theory posits that an upstart's innovations can disrupt an incumbent's dominance (Denning, 2016). Even incremental innovations arising from the ERT mode at institutions (such as those profiled in this article) may quicken migration of higher education to a new pedagogical paradigm. Insights from other learning theories should additionally be considered. Connectivism, posited by George Siemens, specifically "addresses learning in complex, social, networked environments" (Siemens \& Conole, 2011), in response to ongoing influences of the Internet and related technologies. Certainly, theories like these can be juxtaposed when elucidating the trajectory of higher education.

\section{University College London, United Kingdom (Fotini Diamantidaki)}

\section{Nurturing imagination and collaborative co-creation by shared interests:}

\section{Co-creative collaboration nurtures imaginative spirit (Figure 1)}

\section{Overview of higher education at pandemic onset}

The response to the pandemic in the UK has been slow and erratic from the outset. Criticism around lockdown measures and lack of clear guidance is ongoing and we all live the consequences of a prolonged lockdown. Universities across the UK increasingly express their concerns over recruitment, financial implications and behavioral consequences (Universities UK, 2020). The reaction of Universities across the UK however has been proactive and teaching is entirely moved online from the early stages of the pandemic with a focus on wellbeing of students and staff alike (Universities UK, 2020).

University College London (UCL) was founded in 1826 to open up university education in England to those who had been excluded (UNESCO, 2020). In 1878, UCL became the first university in England to admit women as students on equal terms with men (idem). UCL is associated with several major teaching hospitals_-such as the University College London Hospital, the Great Ormond Street Hospital for Children, the Royal Free Hospital, and Moorfields Eye Hospital—that provide healthcare and contribute to medical practice (UCL, 2020c). During COVID-19, multiple research advances are taking place, with a focus on vaccination, rapid testing, and development of 
ventilators for hospital beds (UCL, 2020d). UCL prides itself on being London's global university, with students from 150 countries studying on its campus within a diverse and dynamic student community (UCL, 2020b). UCL is currently ranked eighth among the world's top-ten universities by the QS World University Rankings (2020).

The UCL Institute of Education (IOE) is the education school of UCL, specialising in postgraduate study and research in the field of education and social sciences; it is one of the 11 faculties at UCL. Historically, IOE opened in 1902 as a constituent college of the University of London. Its aim since being established as a college has been to provide teacher education and to train secondary school teachers by offering higher degrees. IOE has the largest portfolio of postgraduate programmes in education in the UK, with over 19,000 students on different postgraduate routes: from the PostGraduate Certificate in Education (PGCE) teacher education courses to Master's level and doctoral programmes. In February 2014, IOE and UCL announced their intention to merge, and the merger was completed in December 2014 (UCL, 2020a). The UCL IOE has been ranked first in the world for education for the seventh consecutive year running (QS Top Universities, 2020).

\section{Sociocultural, geopolitical, and other influences}

The PGCE course feeds in to the wider landscape of Initial Teacher Education (ITE) and it is crucial to examine, as its disruption has considerable implications for a sustained supply of teachers in schools. PGCE is a university face-to-face course that lasts one academic year. This postgraduate course provides Master's credits and offers QTS (Qualified Teacher Status) - a compulsory government requirement to teach in the UK. All PGCE teachers during the course receive a unique teacher number and register with the government as a teacher. The course is a balance between theoretical pedagogy and school practice. All PGCE students start at university in September, with the subject area tutors teaching the specific pedagogy in their discipline area. University input also entails a professional studies programme that allows students to discuss and think about the role of the teacher as a whole.

The professional aspect of the course continues in school and is run by a senior member of the leadership school team; following an intense six-week period input at university with subject and professional studies, students are placed by UCL in their first school placement between October and January. Input from UCL tutors continues throughout the term, with students spending four days in school per week and one day at university, whilst students develop their teaching with the help of school mentors. A full training programme (provided twice a year) is available to our partnership schools. During term time, UCL tutors visit schools to provide support and formative feedback to PGCE students. At the end of January, when students finish first school placements, they return to UCL for three more weeks of input - a combination of theoretical and pedagogical underpinnings, assignments, and preparation for the second placement, which takes place between 
February and May. It was in mid-March, as students were in their second school placement, when COVID-19 caught us (like so many) by surprise.

Face-to-face teaching ceased formally at UCL on 13 March. At that time, PGCE students were still in school placements, as the guidance from the government was "to keep calm and carry on" with all schools still fully operating. Major questions arose during that time on whether we should pull our students out of schools, as well as what that would mean for their degree and qualified teacher status. Questions also arose on the impact for the thousands of international students: Should we advise them to leave the country before lockdown would happen? We then found ourselves in a situation in which international students were asked by their home countries to return whilst still in school placements. Academic staff, as a result, spent inordinate time and effort providing advice and reassurance to very confused students, many of whom could not decide whether to leave or stay as their next step.

Crucial decisions had to be taken quickly, and UCL's response (after the initial general panic) was eventually quite positive, focusing on students' well-being and prioritising family. UCL announced officially on 18 March that all PGCE students were to be pulled out of school; international students were strongly advised to return to their home countries. Soon afterward, the announcement came by the government to close down schools at the end of that week. As many countries then gradually announced lockdown, the UK remained unsure as to which way to go. International PGCE students mostly chose to return to their home countries. UCL also announced that all PGCE students would keep their bursaries (i.e., shortage subjects like PGCE Languages receive government bursaries to train) and would still receive QTS, based on their school experience up to 18 March. School reports and university tutors' judgments are taken into account to grant QTS.

\section{Reflective insight on local response to pandemic}

The debate currently continues on the best mechanisms to support current PGCE students: either as Newly Qualified Teachers in September or by arranging a third school placement. In the meantime, PGCE teaching continues as per UCL's motto of "remote, not distant learning". Our newest ally is Microsoft Teams to stay connected with students and colleagues for class sessions, meetings, and supervision. We set up teaching and learning materials weekly on Moodle (https://moodle.org/), an online university platform allowing students to study prior to the live sessions; we also teach via Moodle Collaborate (https://docs.moodle.org/dev/Collaborate) and its interactive tools.

The PGCE Languages course is currently in its summer term and will be finishing on 23 June. Traditionally, it is the most exciting part of the course when all creative projects come together. Some projects start in school, with PGCE students planning and teaching a series of lessons, as well as reflecting on their own teaching and other students' learning based on school mentors' advice.

With this course aspect no longer possible, we had to rethink not only how to keep the creative 
character of the course alive but also how to keep the students engaged, working, and collaborative. One aspect of creativity that we foster during collaborative projects is what Fisher (2004) describes as "info-structure", meaning "making alliances and benefiting from the distributed intelligence of others" (p.17). Nurturing creativity relies then on "interconnectivity through learning conversations with others" (idem). This aspect takes place during live sessions when we discuss readings along with ideas for the projects, and when students eventually work in collaborative groups.

Another crucial aspect of creativity that we foster is allowing student teachers to consider different possibilities of one idea and helping them to interpret existing situations in a new way (Selkrig \& Keamy, 2017). An illustrative example is the way in which we adapted one of the course projects, the short-film project. Under normal circumstances, this project is mainly run in school placements where students plan and teach a series of lessons leading up to a short film made by and with their pupils in school. During these unprecedented circumstances, students still plan a series of lessons as usual for a secondary school class leading up to the short film. However, the short-film protagonists are PGCE students themselves. As they are not in school but in quarantine, we encourage them to share hobbies and uplifting activities that help them to remain positive.

Following our conversation, all students felt comfortable sharing interests. It was rewarding to see that, based on hobbies, they were already forming groups with common interests. This adaptation of the task allows them to still complete it, whilst thinking about pedagogy, lesson planning, and use of vocabulary and structures at the secondary-school level. Most importantly for me, they learn to use their existing experiences and co-create something new, which, according to Pendleton-Jullian \& Seely Brown (2016), is actually an interpretation of imagination-what they define as "pragmatic imagination". They argue that imagination is not an abstract concept but rather a result of cognitive processes and the formation of mental images. In this view, everything that we see is mediated by images that we hold from past experiences. Indeed, images are personal and cultural interpretations of the "real" experience (Pendleton-Jullian, 2018).

This dynamic definition of imagination posits the theory that everyone has the capacity to imagine and therefore create. It comes as a welcoming response to any person's arguing of being neither creative nor imaginative. Instead, imagination and creativity can be collaboratively nurtured and constructed, allowing everyone to bring individual outlooks and interpretations of the surrounding experiences. This process then collaboratively feeds into constructive co-creation. Technology functions as a facilitator of this process: How to achieve desired outcomes may be changing, but the outcomes themselves may remain constant. 


\section{Copenhagen Business School, Denmark (Karl-Heinz Pogner)}

\section{Transforming higher education into a true community of practice: \\ Deliberate decision-making defines practice (Figure 1)}

\section{Overview of higher education at pandemic onset}

Higher education in Denmark takes place at universities, university colleges, and academies of professional higher education. Most of the higher education institutions (including all universities) are regulated by the Ministry of Higher Education and Science. The eight Danish universities are responsible for the biggest part of the public research and offer research-based higher education at the Bachelor's, Master's, and Ph.D. levels. The financing of the universities primarily comes from government grants (basic research grants, grants for research-based public sector consultancy, and research grants in open competitions). The principal share of public funding for higher education, which is allocated through the taximeter scheme based on student activity (passed examinations), accounts for approximately $67.5 \%$ of the total (CBS, 2020a).

Essentially, almost all education in Denmark is (tuition) free. This tuition-fee-less system applies to not only Danish students, but also students from countries in the Nordic Council or from countries in the European Economic Area or European Union. All Danish citizens (and many others meeting certain criteria) are offered monthly financial aid when studying. The Danish Higher Education is in principle financed by the taxpayers - an approach making citizens, students, the state, government, Parliament, politicians, and employers all salient stakeholders (CBS, 2020a).

Copenhagen Business School, understanding itself as a business university, aims at combining relevance for business, organizations, and society with academic rigor (see Finch et al., 2018). Mission, vision, and strategy had been in the last rounds of consultation and decision-making when society was locked down due to the COVID-19 pandemic. The strategy emphasises both neo-liberal employability (see Wiepke, 2009) of upcoming knowledge workers and the graduates' capability for knowledge building, as well as the personal and social Bildung (Olesen 2011) of students as reflective practitioners (Schön, $1987 \&$ 1983), responsible citizens, and managers. CBS “aims at leveraging global intellectual leadership to transform society with business, tackling challenges with curiosity, creative new ideas, and collaborative engagement" (CBS, 2020b). Education aims to give individual graduates the competencies to be "independent in thinking and collaborative in action, [... and to] balance competitiveness with trustworthiness" (CBS, 2019).

Acquiring these skills, competencies, and capabilities can be supported by the leitmotiv of the independently and critically thinking learner who makes decisions and choices on a well-informed basis, especially when solving wicked or not-well-defined problems. This educational strategy can, 
of course, come under pressure in times of crises; however, as crisis management and crisis communication research tells us, a crisis also opens up opportunities to learn and emerge as a more resilient organization with a stronger reputation (Coombs \& Holladay, 2006). These opportunities can lead to innovative changes overall.

Sociocultural, geopolitical, and other influences

Teaching is, in Danish higher education, often understood as facilitating and supporting students' learning, i.e., not only acquiring but also transforming and building or creating knowledge (Bereiter \& Scardamalia, 2014) and thereby progressing in the Zone of Proximate Development (Vygotsky, 1978). It combines traditional classroom teaching and lectures with one-to-one consultation, group work, seminars, and, in particular, project-based courses with problem-oriented projects, often in areas outside the university. The teaching "must" include methods that can develop the students' independence and ability to create knowledge and to be innovative (Ministry of Higher Education and Science, 2020). Deeply embedded throughout the entire Danish educational culture (see Illeris, 1974), this ideal of the independent learner is a strength of Danish higher education in the context of developing resilient and sustainable solutions for crisis situations: when the educational system itself is under pressure; when "business as usual" no longer remains an option; and when "back to normal" is no longer a viable solution because a "New Normal" has developed.

When the COVID-19 virus reached Denmark [(first case confirmed 27 February; highest incidence of 466 new cases 3 April; general decline thereafter (Norrestad, 2020)] and began to become both a global and national pandemic, the Danish society, including the private and public sectors, was locked down quickly by the Danish (minority) government. The Health Authorities and all parties in Parliament backed the governmental decision. Schools, high schools, and all higher education institutions closed immediately. The universities instantly declared transformation of all activities (education, research, administration) into digital and online activities. Both full-time academic staff (with research, teaching, supervision, and examination obligations) and a huge number of external part-time teaching staff (carrying out research-based teaching, advising, supervision, etc.) were expected to organize teaching from home offices. At the same time, students were expected to move into home study rooms, using digital communication and remote learning. Hence, remote teaching and online learning became the New Normal for all teachers and students.

The technical part of this transformation/transition was a minor problem because the infrastructure (hard- and software) was more or less in place; in fact, Denmark ranks rather high in different digitalization indices (e.g., DESI, Digital Economy and Society Index; and DiGix, Digitalization Index). As about $20 \%$ of the full-time students are international students, those students also had the chance to study and do their individual and/or group projects from "home" (i.e., wherever they were 
living or staying). Teachers had to learn by learning-by-doing how to teach, supervise, advise, and coach (groups of) students in a kind of Emergency Remote Teaching (Hodges et. al. 2020). Students had to learn how to learn in synchronous and asynchronous settings and how to conduct their problem-oriented (group) projects under lockdown conditions for universities, organizations, and society (often locations for their investigations and projects).

Teachers and students began to muddle through the situation; the official motto (given by the Dean of Education) became "OK is good enough — for now". But much creativity and innovation also had been set free. The majority of online teaching, supervising, and feedback was evaluated as "OK" by students - and sometimes as "surprisingly good under the given circumstances".

\section{Reflective insight on local response to pandemic}

Teachers (both full-time academic staff and external part-time teachers) began to organize online meetings to share experiences-sometimes together with students. These bottom-up initiatives, a kind of "Community of Common Destiny", have been focusing primarily on Ed-Tech, how to cope with the situation, how to "survive", and how to reach the aforementioned "OK". Conversations still are primarily spinning around the questions of how to teach online. To a much lesser degree, conversations and courses reflect on how to learn and even less on questions of what students should learn and acquire and why they should learn it - despite the fact that the answers to these questions should be the basis for the decision of how.

Almost never in this transition phase were questions raised about how Emergency Remote Teaching (ERT) could be transformed into sustainable, resilient, reflective, blended (f2f and online/digital) learning: a pedagogy that could incorporate well-known concepts like learning to learn, problem orientation, participant-managed project work, student-centred supervision (Ankersborg \& Pogner 2020), and academic literacies (Lilies et al., 2015) in order to come closer to the transformative ideal of the independent and critical learner. The New Normal should not only include transparency about the learning objectives of CBS's mono-disciplinary and multi-/interdisciplinary programs and courses, but also the alignment of expectations for how to organize (online) teaching, supervision, and learning. Furthermore, it should encompass transparency and reflection about expectations, norms, and genres of academic Discourse Communities and academic Communities of Practice (Nystrand, 1982; Swales, 1990; Lave \& Wenger, 1991; Pogner, 2012) so as to empower students to grow into the identity of legitimate - albeit peripheral-participants, acquiring and developing competencies for themselves, organizations, Denmark, and the global society.

After two months of lockdown, all parties of Parliament agreed on a step-by-step, careful, and prudent reopening of the private and public sectors, along with the social life of our citizens. Still, many restrictions will constrain everybody's daily life and operations of universities in the future. CBS buildings will remain closed this semester, all written and oral exams (the latter often based on 
written synopses, essays, internship reports, mini- or year-long projects, and Bachelor's or Master's theses) will be conducted online. In the next semester, all lectures must "go digital", and 50\% of all activities (exercises, seminars, workshops, etc.) must be digital when/if universities open partially. This New Normal offers the opportunity to transform the pre-corona practice and emerged corona emergency teaching into online and offline "conversations [that] should not be understood as a technique to transmit knowledge, insight, and experience between individuals. A conversation is a human activity that contributes to that we develop our understanding of the world and strengthens our capability to reflect" (Lauvås \& Handahl, 2006). Preconditions for this approach and for a changed practice are meta-competencies for critical reflection, independence, and argumentation of teachers and students - no matter if they have grown up in an educational culture fostering these meta-competencies or if they are encountering them for the first time. As an outgrowth from the pandemic's disruption, the Community of Destiny (Pogner \& Søderberg, 2003) could become a Community of Practice for the world of higher education. 


\section{Royal Roads University, Victoria, British Columbia, Canada (Carolin Rekar Munro)}

\section{Galvanizing leadership of change with empathy in an unknown future: Programs offer guidance and leadership for students (Figure 1)}

\section{Overview of higher education at pandemic onset}

That which once seemed an improbability became our reality. The pandemic crept with stealth into Canada, causing the Canadian economy to hemorrhage and putting the normality of our lives in a coma. My academic home, Royal Roads University (RRU), along with other post-secondary institutions in British Columbia, was declared a non-health emergency service for the purposes of delivering remote learning (Government of British Columbia, 2020).

The Government of Canada, through the Incident Response Group on Coronavirus, established the infrastructure to contain the virus and mitigate the crisis. Their response plan was guided by the following principles: collaboration with provincial and territorial government leaders to ensure a harmonized response in the health system; evidence-informed decision-making; proportionality of response to the level of threat; and flexibility to tailor actions as new information surfaces. Immediate responses included funding for borders and travel measures; repatriation of Canadians; sustainability of the National Microbiology Laboratory, which oversees testing; and funding for vaccine and antiviral development and clinical trials (Government of Canada, 2020a).

Canada's Public Health Agency ramped up its communication and public education efforts. Access to daily updates and health self-assessments are available through Canada's coronavirus website, the COVID-19 app on iOS and Android, and an information hotline. Daily, Prime Minister Justin Trudeau delivers an update from his home, followed by debriefings from Canada's Chief Health Officer. Leadership messages_-such as "flatten the curve", "go home and stay home", and "it's for now, not forever" - are frequent and pervasive. Moreover, these anthems have joined the lexicon of our time (Public Health Services of Canada, 2020).

For individual Canadians, first implemented was the Canada Emergency Response Benefit, which provides $\$ 2,000$ monthly to workers who lost their income. Available for students (without summer jobs from May-August 2020) is the Canada Emergency Student Benefit, which provides \$1,250 monthly for students or $\$ 1,750$ monthly for students with dependents or disabilities. Increased funding was given to local food banks to purchase and distribute basic necessities to Canadians in need; homeless shelters to provide additional beds and barriers for physical distancing and to convert stadiums and hotels into temporary lodging for the homeless; women's shelters and sexual assault centres to protect women and children fleeing violence; centres for seniors to provide delivery of food and medication and to accompany them to doctor appointments; and a "Kids Help 
Phone" to provide mental health support to children. Homeowners facing hardship are eligible for mortgage payment deferral (Government of Canada, 2020a).

Businesses are also on the receiving end of government assistance. To avoid layoffs, employers are eligible for the Canada Emergency Wage Subsidy, covering up to $\$ 847$ per week of an employee's wages. Two key programs are in place for small businesses: 1) the Canada Emergency Business Account, which provides interest-free loans of \$40,000; and 2) the Canada Emergency Commercial Rent Assistance, which lowers rent by $75 \%$ for businesses affected by COVID-19 (Government of Canada, 2020a).

As of 30 April, the daily increase of COVID-19 cases nationally slowed to 3\%, down from $31 \%$ in mid-March (Government of Canada, 2020b). This dramatic drop mobilized government leaders to chart plans for reopening the economy. Given regional differences in case numbers, each province has jurisdiction to lift restrictions based on medical intelligence from provincial health officers. Canada's Chief Public Health Officer offered reason for optimism, yet Canadians must continue to practice safe distancing to minimize the occurrence of a second wave of the pandemic (Government of Canada, 2020c).

\section{Sociocultural, geopolitical, and other influences}

Established in 1995, RRU is a small, private university that has graduated over 20,000 students in the fields of leadership, business, environment, communication, tourism, hospitality, and social justice who contribute to their communities in over 60 countries. RRU offers applied and professional programs at the undergraduate, graduate, and doctoral levels, as well as certificates, diplomas, executive, custom, and continuing education. Our cohort-based programs are offered in three formats: 1) on-campus classes, 2) blended, combining online courses with residencies ranging from one to three weeks; and 3) completely online learning (Royal Roads University, 2020).

RRU is tucked away on 565 acres of oceanfront and old-growth forest located in Hatley Park National Historic Site on Vancouver Island - the far west coast of Canada. On the ancestral homelands of the Xwsepsum and Lkwungen nations, RRU was originally the site of the Royal Roads Military College. Emblazoned on signage at the entrance to RRU is Life. Changing, which signifies the most frequently articulated experience by students (Royal Roads University, 2020).

The centerpiece of RRU's approach to pedagogy and research is its Learning, Teaching, and Research Model (LTRM). Grounded in the caring, accountable, and creative values of RRU, LTRM serves as the cornerstone for recruiting and developing faculty. It consists of three core categories: 1) applied and authentic (interdisciplinary and transdisciplinary; experiential and participatory; and, outcomes-based); 2) caring and community-based (co-creative; and place- and virtual space-based); and 3) transformational. The aim of the LTRM is to provide the architecture for creating innovative 
and immersive experiences for students, thereby fostering their development as lifelong learners who are adept at real-life problem solving (Royal Roads University, 2019).

When WHO declared the global pandemic, RRU began migrating all on-campus programs and residencies online - a plan tentatively in place until December. With 25 years' experience designing and facilitating synchronous and asynchronous online courses, RRU is positioned to manage this transition. The faculty's fluency in the virtual playground, guided by RRU's Centre for Teaching and Educational Technologies, is creating a relatively seamless continuation of student learning. Still, heavy lifting remains, especially migration of three-week residencies from on-campus to virtual formats and administration of online examinations. Moodle (https://moodle.org/), RRU's delivery platform, is being tested to its fullest with podcasts, digital storyboards, student-generated vodcasts, simulations, live cases, and breakout rooms for team-building and collaboration. Padlet (https://padlet.com/) is also being used for teams to co-discover and co-create learning.

RRU's President convened a COVID-19 committee with representation for academics, student life, communications, facilities, international students, and study abroad. Through weekly email broadcasts and video messages, he addresses the community with messages of gratitude for the work done, hope for the future, and an overview of response plans in play. To ease the hardships for students, emergency financial support is available, as a result of additional funding from the British Columbia government; late tuition payment fees are suspended; and a monthly tuition payment plan is available. Online mental health counseling is available, along with weekly wellness workshops (Royal Roads University, 2020).

\section{Reflective insight on local response to pandemic}

With daunting speed, students are wrestling with complicated and complex transitions. Their world shifted drastically with abrupt curricular modifications and sudden loss of on-campus community, residencies, jobs, research projects, international study pursuits, and convocation. For some, these challenges were compounded by a lack of basic infrastructure for online connectivity, time-zone differences, and health concerns for themselves and loved ones. A breakdown in mental health was triggered, impeding students' abilities to be fully present, focused, and productive during clases.

The pandemic demands that faculty plan for an unknown future, innovate with urgency, and evolve new ways of thinking about teaching and learning; equally imperative is being mindful of and attentive to students' well-being. We can play a vital role in relieving some of the heaviness that students feel, uplifting their optimism and hope, and fostering their resilience in a world spinning out of their control. In so doing, our online classrooms can serve as a regenerative home and a temporary haven from the madness of the crisis. 


\section{Glocalising the Localised Responses}

\section{Exploration of Themes by Level}

As dedicated researchers during this pandemic, we have not only much to discover but also many opportunities for re-imagining our paradigm of higher education. In fact, the very nature of this pandemic suggests using a "novel" form of analysis. Consider the approach used in public health to investigate, mitigate, and eradicate the "novel" coronavirus - epidemiology:

The word epidemiology comes from the Greek words epi, meaning on or upon, demos, meaning people, and logos, meaning the study of. In other words, the word epidemiology has its roots in the study of what befalls a population [emphasis added] (CDC, 2020d, n.p.). In the arena of public health, epidemiologists investigate tentative causes, predetermining factors, geographic distribution, and temporal trends for diseases or other health events, in order to postulate and test explanatory models; such analytics can indicate potential solutions. Everyone is now keenly aware of these parameters as related to COVID-19 from a medical perspective, but these parameters can be extrapolated to higher education during this pandemic.

That is the crux of this article. Each section has examined an institution within a nation, looking at its localised responses in three areas:

- pandemic onset (geographic distribution and temporal trends)

- other influences (tentative causes and predetermining factors)

- reflective insight (explanatory models and potential solutions)

At the localised stage of this pseudo-epidemiological analysis, clusters of shared issues have been identified on the curricular, institutional, and technological levels. In particular, distinct patterns of responsiveness at the curricular level, recommitment at the institutional level, and reprioritization at the technological level have emerged. The following text explores these three patterns in an attempt to draw together anecdotal data across the seven institutions. Figure 2 visually encapsulates our own feelings at two stages: (a) the peri-pandemic stage of our localised responses to the pandemic; and (b) the post-pandemic stage of a glocalised paradigm. ${ }^{18}$

\footnotetext{
${ }^{18}$ Creanne-team sketches by Anne Pässilä; photos by Jussi-Pekka Kekki.
} 


\section{Table 2. Clusters of glocalised themes built from localised observations to the COVID-19 pandemic}

\begin{tabular}{|c|c|c|}
\hline Glocalised Themes & Localised Observations & "Nation(s) \\
\hline \multirow[t]{3}{*}{ ERT as disruptive "stepping stone" to future } & ERT as innovative disruptions leading to innovations & Singapore, US, Denmark \\
\hline & Situational flexibility in remote teaching and learning & US \\
\hline & Community of destiny vs. practice over the long-term & Denmark \\
\hline \multirow[t]{3}{*}{ Expanded definition of faculty expectations } & Melding of categories for on-campus with off-campus & Singapore \\
\hline & Imaginative, collaborative, and co-creative parameters & UK \\
\hline & Empowered resilience and flexibility for the unknown & Denmark, Canada \\
\hline \multirow[t]{3}{*}{ Wider inclusivity across student populations } & Age expansions, societal inequities, and special needs & Greece, US, Canada \\
\hline & Partnerships with school systems for lifelong learning & UK \\
\hline & Multi-dimensional and holistic well-being of students & UK, Australia, Canada \\
\hline \multirow[t]{3}{*}{ Research-driven scholarship into pedagogies } & Teacher education addressing new models of learning & Greece, Canada \\
\hline & Data-driven research to reduce online-learning stigma & Singapore, US, Australia \\
\hline & Enhanced leadership forms at all levels to drive vision & Canada \\
\hline
\end{tabular}




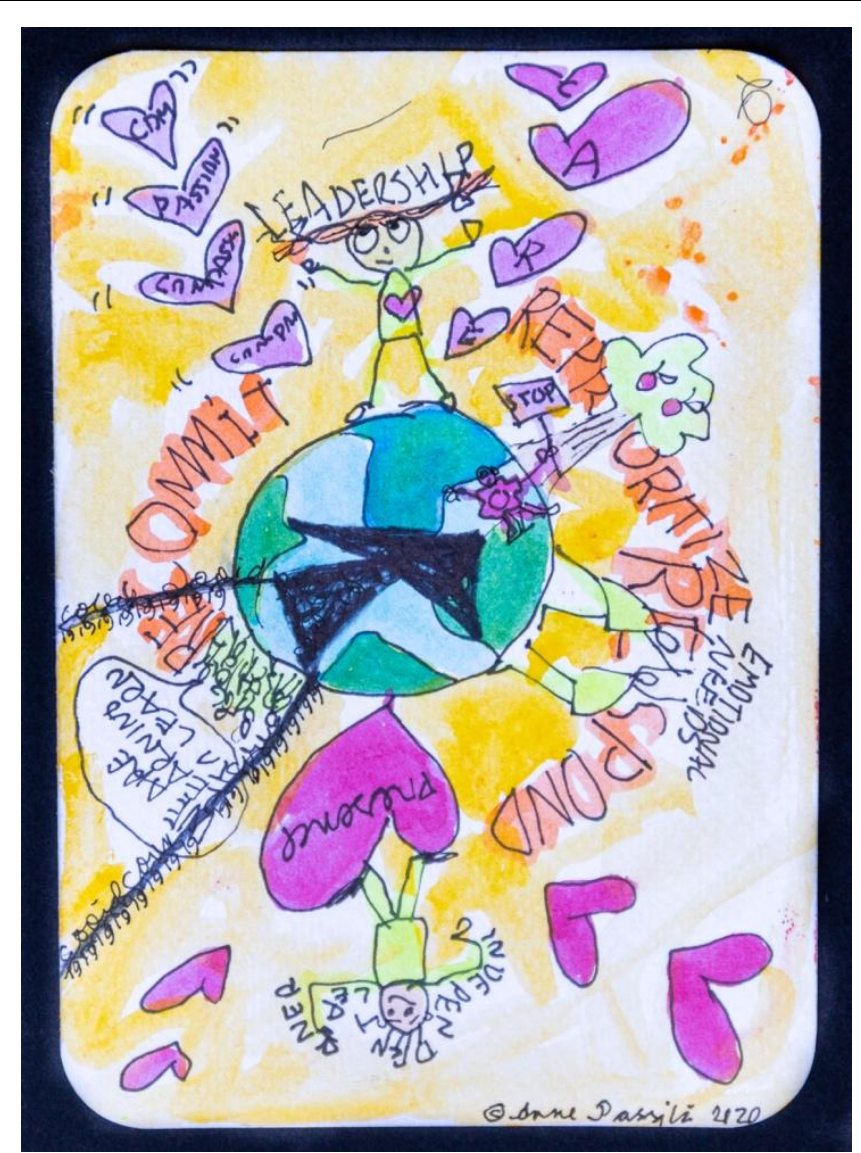

Figure 2(a) Localisation

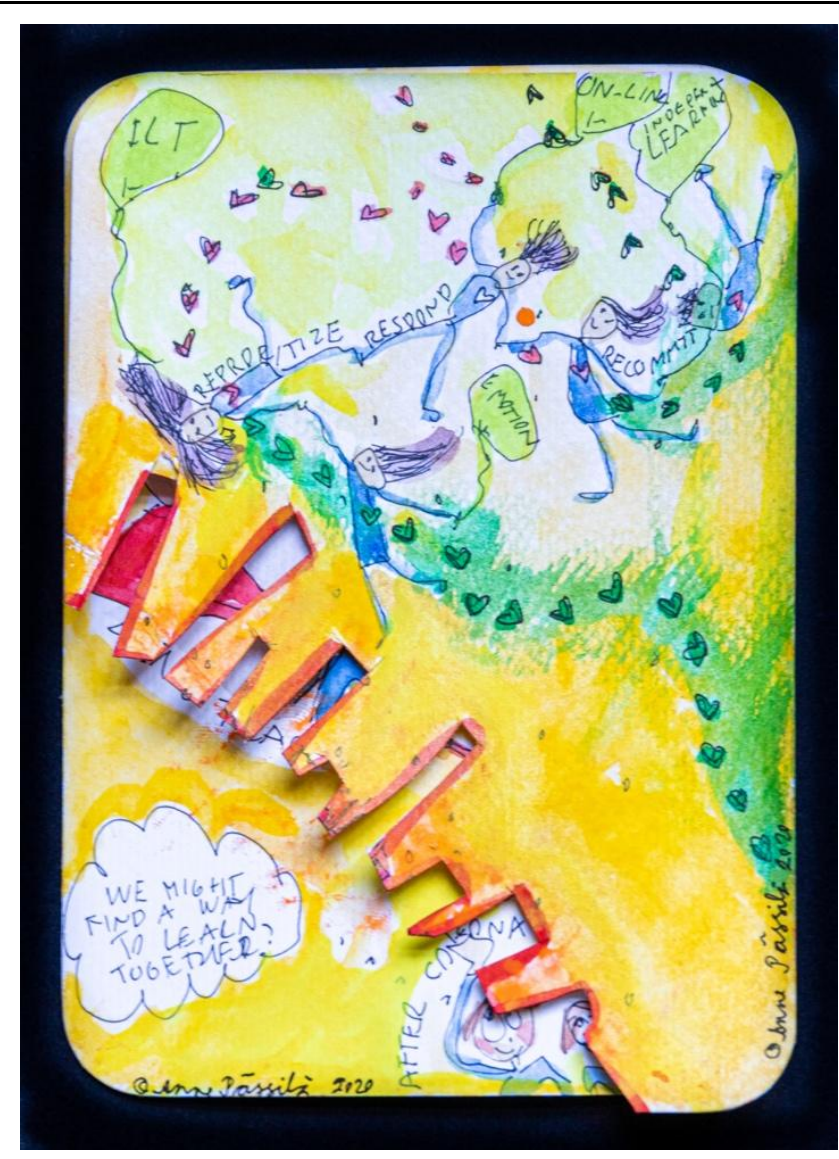

Figure 2(b) Glocalisation

Figure 2. Artistic representations of the transition of higher education from (a) localisation to (b) glocalisation

Creanne-team sketches by Anne Pässilä; photos by Jussi-Pekka Kekki. 


\section{Curricular Level-Responsiveness}

The transition to digital learning cannot be solely a technological transfer of course materials to a learning management system. Although some course components may easily be transposed, others require flexibility and adaptability; team projects and community outreach, as examples, require student-teacher negotiation for underlying goals of such assignments to be achieved. Nonetheless, provisions for alternative modes of earning course credit are needed, particularly as students cope with technological challenges, shaken confidence, and mental stress. Faculty need to consider all these holistic dimensions as they respond to students' learning needs.

\section{Institutional Level_Recommitment}

Addressing the disruption of this pandemic (and potentially other cataclysms), administrators must see the learning process as an investment rather than an expenditure, particularly in our knowledgebased economies. Educators must be supported as they delve into the scholarship of online delivery. Moreover, in moving beyond the ERT mode, higher-education institutions can proactively assess and plan for online pedagogies, community outreach, and collaborative co-creation. The lost sense of community is also a crucial consideration - for students and faculty alike. Empowered resilience with a splash of empathy can support these efforts pedagogically.

\section{Technological Level—Reprioritization}

As higher education emerges from the crisis-driven transition, the impetus for innovation must not be squandered. Technological details_-whether synchronous/asynchronous models, online modes of advising and counseling, or time-zone connectivity - can be addressed operationally; however, strategic decisions at the start must be prioritized for learning to be geographically remote but not pedagogically distant. These considerations extend beyond administrative halls: Faculty must be open to learning not only communication technologies but also multiple disciplines so as to adapt when the unexpected happens yet again.

\section{Exploration of Themes by Cluster}

As in epidemiological studies, collected data can be viewed and examined from different vantages. Complementing the more localised responses at curricular, institutional, and technological levels (as just done in the preceding subsection) is a synthesis to reveal themes of a more glocalised nature. Four thematic clusters emerge, as summarized in Table 2 and explored below. 


\section{Cluster 1-Disruptive Innovation}

Although the hardships unleashed by the pandemic can in no way be considered a blessing, their resultant disruption to the status quo does offer an opportunity for innovation. Essentially, higher education is now moving from (borrowing a medical metaphor) the emergency department and intensive care unit to the post-operative ward-and eventual discharge. According to Christensen's disruption theory (elaborated in Denning, 2016), incremental changes - if innovative - can erode established norms. Hence, the ERT mode can be a "stepping stone" to higher education not as the destined but as the definers of new academic Communities of Practice (Pogner, 2012).

\section{Cluster 2-Faculty Redefinition}

The pandemic has clearly highlighted the need to reconsider the traditional definition of "faculty". Providing discipline-specific content, of course, does not change; however, the manner in which content is delivered is reshaping the expectations for faculty. Knowledge outside one's disciplineespecially but not exclusively technological expertise - requires faculty to stay on the leading edge of ongoing and future developments in higher education. Certainly, the delivery of content must now consider the dialogic context of that delivery (Britzman, 2003), particularly for confidence, emotions, imagination, resilience, and other holistic dimensions of education.

\section{Cluster 3-Expanded Inclusivity}

Education is no longer demarcated by years of study or presence in classrooms. Rather, education is more fittingly viewed as lifelong learning. European institutions of higher education, recognizing demographic shifts in student populations, are developing non-degree programs for working adults and other individuals who may not want or need a degree (Henderikx \& Jansen, 2018). Additional groups, especially those with socioeconomic or functional deterrents, must also be accommodated as education shifts toward digital modes of delivery. The flexibility inherent in virtual learning can be harnessed to support this expanded inclusivity.

\section{Cluster 4-Pedagogical Research}

For digital learning to be fully respected in higher education, researchers must emphasize a more rigorous focus on pedagogical scholarship. In essence, the core approach to "educating educators" can be enhanced by reliable studies of the practice of teacher education (Britzman, 2003). In light of an expanding inclusivity of education, institutions should develop deliberate strategies for joining efforts with the school system. Nonetheless, this challenging vision of a new paradigm necessitates 
leadership across the educational panorama (Henderikx \& Jansen, 2018). Educational leadership, in and of itself, deserves more attention (beyond this paper) in rigorous scholarship.

\section{Exploration of Themes by Reflection}

Just as public health focuses on the group rather than the individual, so too has our epidemiological approach to glocalisation of higher education during this time of pandemic. Individual contributions have teased at the humanisation of our research. Although an expansive examination of these critical considerations would need to (and should) be tackled in a separate but complementary research study. Nonetheless, the following piece-eloquently captured by Carolin Rekar Munro-reflects on lessons learned by one of our co-authors.

In the trenches of this crisis, educators are humbly on the receiving end of many lessons that guide teaching and learning during and through crisis. The ongoing transition relies on three overarching parameters: leadership, empathy, and structure.

First, true leadership - the leadership that galvanizes and inspires-shows up in times of crisis. It is during the most distressing times in our collective lives that we thirst for someone to lead us through and out of pain. For it is in times of crisis that the real leaders show up: early and often; wielding strong and enduring values as their compass; maintaining clarity in their mission; and offering an abundance of faith, hope, and light. Ultimately, a leader helps people to gain traction during distraction by leveraging optimism and realism (Heifetz et al, 2009) and "feeding faith and starving fears" (Maxwell, 2020). It is this leadership that, we, as faculty, are called to exemplify.

Our students, who are exhausted and overwhelmed, are in need of someone who is calm, consistent, and firm; offers prudent advice as the precursor to making smart decisions; and has a steady hand to steer them in and through adversity. At this time, we must expand communication with our students through virtual office hours and regular check-ins, thereby signaling to students that we are here for them and receptive to connecting with them on issues that matter most to them. Communication also positions us to refer them to assistive facilities, such as wellness counselors, accessibility services, learning coaches, and financial services.

Second, empathy is the fastest way for us to build trusting and respectful connections with our students, especially during times of distress. Empathy is the artfulness of "seeing with the eyes of another, listening with the ears of another, and feeling with the heart of another" (Adler, 2016). It begins with being cognizant of our internal dialogue, which is a primary determinant of whether connections with our students will be arms-length transactions or meaningful alliances. Our inner voice - with its intricately woven web of values, beliefs, attitudes, and assumptions —shapes not only our thinking, but also our speech and our behaviours. For the most part, we do not even realize the 
domino effect that our private thoughts have on how we act and react to others, as well as how our students experience us.

During the pandemic, our students may be acting and reacting in ways that are counter to our own ways of responding; they may be testing our patience and draining our mental, physical, and spiritual energy. We must, at all times, be cognizant of the lens through which our students perceive and experience the world. Such cognizance is the heart and soul of empathy. Specifically, we are called to shift gears and enter into dialogue with care, compassion, and curiosity about the world of our students; and to strive to comprehend and appreciate them, regardless of how divergent their beliefs, values, and response behaviours are from our own. We are invited to ask more questions, leave more space in conversations for students to share their stories, put our assumptions and judgments in abeyance, and generatively listen-a form of "communion or grace that is our capacity to connect to the highest future possibility that can emerge" (Scharmer, 2008).

Third, structure and routine provide students with the comforts of certainty, consistency, and stability in a world that is spiraling out of their control. The anxiety experienced by students can be tempered when students know that a carefully crafted framework exists for their learning. Upfront, let us provide clear course and instructor expectations; hold space for students to articulate their expectations of the course and us; and encourage students to organize their day with the routine of making a daily calendar with set time to study, network, have lunch, and take physical activity breaks. As well, let us make clear our expectations of how time will be used synchronously and asynchronously. Since synchronous learning can lead to cognitive overload and fatigue, we must preserve this time as sacrosanct for 30-45 minutes of content that drives value and inspires action (Clark \& Sweller, 2011). Anxiety reduces the ability to process information by $80 \%$, shrinks attention span to 12 minutes, and limits capacity to retain any more than three main ideas (Goodwin, 2019).

Whether we are leading at the government level, for our university, or in our classroom, no existing playbook prescribes the pathway for dealing with a global pandemic of this magnitude. Our local and glocal responses require leadership-from all of us-that leverages a firm and steady presence, care and compassion for each other, and prudent decision-making. With these qualities in hand, we will be even better prepared to plan for an unknown future, galvanize change with urgency, and gain ground in a COVID-19 reality. 


\section{Conclusions on Shifting to Glocalisation}

Unlike a globalised response that would adopt one approach internationally, our study considered adaptations for local differences in a glocalised set of responses toward an attempt to identify new paradigms that reconceptualize not only teaching and learning, but also assessment. Moreover, identified issues indicate shared threads across the seven institutions of higher education.

From a localised perspective emerge responses at the curricular, institutional, and technological levels. First, changes to courses and curricula must respond to emotional needs of students when transitioning from face-to-face (or hybrid) to online delivery; nevertheless, faculty must ensure that academic rigor is not sacrificed in the process. Second, the mission and value of higher education must indicate that institutions will recommit to faculty support beyond emergency remote teaching; furthermore, a sense of campus community needs to be nurtured. Third, the needs of students and faculty must drive the choices of technology — not the reverse - when determining how to transition to online deliveries; in short, administrators must reprioritize decision-making factors.

Moreover, a glocalised synthesis across all institutions and levels identified four clustered themes. First, disruption from the pandemic may lead to innovations in higher education. Second, the role of faculty is becoming redefined beyond content-specific disciplines. Third, educational models must expand to individuals other than the traditional student. Fourth, rigourous pedagogical scholarship, including leadership, will point to new educational insights. Any or all of the themes explored in this article could serve as a topic for future research.

Overall, our findings indicate that we stand at a crossroads. Rather than be defined by the pandemic, let us seize this offered opportunity to transform higher education from a paradigm that has been to the paradigm of what might be. The opportunity is ours to choose or to lose.

Acknowledgment: Our grateful thanks to Ms. Shannon Tan, Research Intern at Kaplan Singapore, for her valuable research assistance. We are especially indebted to the Creanne-team, who visually captured our own spiritual transition in sketches by Anne Pässilä and photos by Jussi-Pekka Kekki. Additionally, we thank our three anonymous reviewers, whose insightful comments have contributed to ensuring and improving the quality of our paper. 


\section{References}

Adult Education and Training. (2018, December 19). https://eacea.ec.europa.eu/nationalpolicies/eurydice/content/adult-education-and-training-25_en

Alachiotis, N.S. Kalavruziotis, G., Lionarakis, A., Orfanoudakis, T., \& Stavropoulos, H.K. (2019).

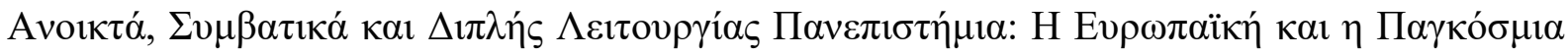

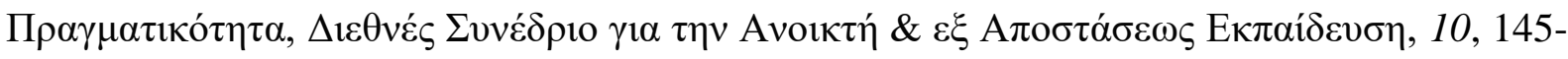
161. https://eproceedings.epublishing.ekt.gr/index.php/openedu/article/view/2328

Ang, H. M. (2020a, March 30). 2,300 polytechnic and university students asked to return from overseas placements amid COVID-19 pandemic: MOE. Channel News Asia. https://www.channelnewsasia.com/news/singapore/2-300-polytechnic-and-universitystudents-asked-to-return-from-12588588

Ang H. M. (2020b, April 3). Local universities cancel in-person examinations, move assessments online. Channel News Asia. https://www.channelnewsasia.com/news/singapore/covid-19$\underline{\text { universities-ntu-smu-cancel-in-person-examinations-12607906 }}$

Ankersborg, V. \& Pogner, K.-H. (forthcoming). Conform. Transform. Resist: What can we learn from the Scandinavian way of Master thesis supervision and its contribution to acquiring research literacy and practice? In Gustafsson, M. \& A. Eriksson (Eds.). Academic writing at intersections in Europe. Fort Collins, CO: WAC Clearinghouse \& Colorado State University Open Press.

BBC (2020, April 23). Coronavirus: Australia urges G20 action on wildlife wet markets. https://www.bbc.com/news/world-australia-52391783

Bereiter, C. \& Scardamalia, M. (2014). Knowledge building and knowledge creation: One concept, two hills to climb. In Tan, S.C., So, H.J. So, \& Yeo, J. (Eds.). Knowledge creation in education. Singapore: Springer 35-52.

Bonk, R. J. (2013). Experiential civic engagement in professional writing: A 10-year case study of active-learning pedagogy at a metropolitan university. In P. Fitzsimmons, Z. Charalambous, \& S.L. Wiesner (Eds.). Spectrums and spaces of writing [eBook] (pp.181-190). Oxford, United Kingdom: Inter-Disciplinary Press. (2011, November). Talk presented at $1^{\text {st }}$ global conference on writing: Paradigms, power, poetics, praxes / Critical thinking across dimensions, Prague, Czech Republic.

Bonk, R. J. (2016, April). Open access education in professional writing: The LOOC model of Widener University. [Action Lab]. Talk presented at Open education global conference 2016. Krakow, Poland. 
Bonk, R. J. (2019, April). Technologically enhanced pedagogies in professional writing. Journal of Applied Learning and Teaching, 2(2), 17-23.

Britzman, D.P. (2003). Practice makes practice: A critical study of learning to teach. (Rev. ed.). Albany: State University of New York Press. http://ebookcentral.proquest.com

Centers for Disease Control and Prevention. (2020a). Coronavirus (COVID-19). https://www.cdc.gov/coronavirus/2019-ncov/index.html

Centers for Disease Control and Prevention. (2020b). Interim guidance for administrators of US institutions of higher education: Plan, prepare, and respond to Coronavirus Disease 2019 (COVID-10). $\quad$ https://www.cdc.gov/coronavirus/2019-ncov/community/guidance-ihe$\underline{\text { response.html }}$

Centers for Disease Control and Prevention. (2020c). Previous U.D. COVID-19 case data. https://www.cdc.gov/coronavirus/2019-ncov/cases-updates/previouscases.html

Centers for Disease Control and Prevention. (2020d). Introduction to epidemiology: Definition of epidemiology. In Principles of epidemiology in public health practice: An introduction to applied epidemiology and biostatistics. ( $3^{\text {rd }}$ ed.). (2011, November update). [Online textbook]. https://www.cdc.gov/csels/dsepd/ss1978/lesson1/section1.html

Channel News Asia. (2020, March 16). Universities, polytechnics suspend overseas placements as Singapore widens border restrictions. https://www.channelnewsasia.com/news/singapore/ $\underline{\text { coronavirus-singapore-universities-polytechnics-suspend-overseas-12540158 }}$

Clark, A. J. (2016). Empathy and Alfred Adler: An integral perspective. Journal of Individual Psychology, 72, 237-253.

Clark, R. C., Nguyen, F., \& Sweller, J. (2011). Efficiency in learning: Evidence-based guidelines to manage cognitive load. John Wiley \& Sons.

Coombs, T. \& Holladay, S.J. (2006). Unpacking the halo effect: Reputation and crisis management. Journal of Communication Management 10(2), 123-137 [DOI: 10.1108/13632540610664698] Copenhagen Business School. (2019). CBS' duty toward society: Building the 'Nordic Nine' capabilities [Internal document].

Copenhagen Business School. (2020a). Facts and figures. Copenhagen: Copenhagen Business School. https://www.cbs.dk/files/cbs.dk/call_to_action/factsandfigures2019_til_web_0.pdf

Copenhagen Business School. (2020b). CBS strategy-Draft for the local meetings [Internal document].

Copenhagen Business School. (2020c). Corona virus update. https://www.cbs.dk/en/thepress/news/coronavirus-update-0 
Craven, M., Liu, L., Mysore, M., \& Wilson, M. (2020). COVID-19: Implications for business. McKinsey \& Company. https://www.mckinsey.com/business-functions/risk/ourinsights/COVID-19-implications-for-business

Crawford, J., Butler-Henderson, K., Rudolph, J., Malkawi, B., Glowatz, M., Burton, R., Magni, P., Lam, S. (2020). COVID-19: 20 countries' higher education intra-period digital pedagogy responses. Journal of Applied Learning and Teaching, 3(1). Advanced online publication.

Data USA. (2020). Chester, PA. https://datausa.io/profile/geo/chester-pa/

Delaware County (2020). Coronavirus COVID-2019. https://www.chesco.org/4376/CoronavirusCOVID-19

Denning, S. (2016). Christensen updates disruption theory [Masterclass]. Strategy \& Leadership 44(2), 10-16. DOI:10.1108/SL-01-2016-0005

Department of Statistics, Singapore. (2020). Latest data. https://www.singstat.gov.sg/finddata/search-by-theme/economy/national-accounts/latest-data

Economic Review Committee. 2003. Panel recommends Global Schoolhouse concept for Singapore to capture bigger slice of US\$2.2 trillion world education market. Singapore:

Economic Review Committee. https://www.mti.gov.sg/ResearchRoom/Documents/ app.mti.gov.sg/data/pages/507/doc/DSE recommend.pdf

Ehrhardt, C. \& Fähnders, T. (2020, April 24). Menschliche Einwegware. Frankfurter Allgemeine Zeitung, $\quad$ https://www.faz.net/aktuell/politik/ausland/corona-pandemie-gastarbeiter-sindbesonders-betroffen-16738810.html

Elmabruk, R. (2020, April 20). To what extent is Corona-virus pandemic impacting modes of teaching and learning in Higher Education? https://www.researchgate.net/post/ To what extent is Corona-

virus pandemic impacting modes of teaching and learning in Higher Education

Euricide. (2018, December 19). Adult education and training.

https://eacea.ec.europa.eu/nationalpolicies/eurydice/content/adult-education-and-training25 en

Fahrion, G. (2020, April 24). Das Musterland kommt ins Straucheln. Der Spiegel, https://www.spiegel.de/politik/ausland/singapur-kampf-gegen-raschen-anstieg-der-covid-19infektionen-a-91c97ba7-c21e-49f7-888d-ae85bd56f86b

Finch, D., Falkenberg, L., McLaren, P.G., Rondeau, K.V. \& O’Reilly, N. (2018). The rigourrelevance gap in professional programs: Bridging the 'unbridgeable' between higher education and practice. Industry and Higher Education 32(3), 152-168. https://journals.sagepub.com/doi/10.1177/0950422218768205 
Fisher, R. (2004). What is creativity? In R. Fisher \& M. Williams (Eds.), Unlocking creativity: Teaching across the curriculum (pp. 6-20). Milton Park: David Fulton Publishers.

Frankenberger, K.-D. (2020, April 23). Fragen über Fragen. Frankfurter Allgemeine Zeitung, https://www.faz.net/aktuell/politik/ausland/bilanz-der-corona-krise-die-fragen-werden$\underline{\text { kommen-16737060.html }}$

Garrett, R. (2005). The rise and fall of transnational higher education in Singapore. International Higher Education, 39, 9-10.

Goodwin, D. K. (2019). Leadership: In turbulent times. New York: Simon \& Schuster.

Government of British Columbia. (2020). COVID-19 essential services. https://www2.gov.bc.ca/gov/content/safety/emergency-preparedness-response$\underline{\text { recovery/covid-19-provincial-support/essential-services-covid-19 }}$

Government of Canada. (2020a). Canada's COVID-19 economic response plan. https://www.canada.ca/en/department-finance/economic-response-plan.html

Government of Canada. (2020b). Coronavirus disease (COVID-19): Outbreak update. https://www.canada.ca/en/public-health/services/diseases/2019-novel-coronavirusinfection.html?topic=ex-col-faq\#a1

Government of Canada. (2020c). Coronavirus in Canada: These charts show how our fight to "flatten the curve is going". https://www.macleans.ca/society/health/coronavirus-in-canadathese-charts-show-how-our-fight-to-flatten-the-curve-is-going/

Health Equity Initiative. (2020). https://www.healthequityinitiative.org/

Heifetz, R., Grashow, A., \& Linsky, M. (2009). Leadership in a (permanent) crisis. Harvard Business Review, 87(7/8), 62-69.

Hein, S. (2020, April 9). Eingeschlossen im Containerdorf. Frankfurter Allgemeine Zeitung, https://www.faz.net/aktuell/wirtschaft/corona-krise-in-singapur-eingeschlossen-imcontainerdorf-16718579.html

Heng, J. (2020, May 13). Details out next week, on first sectors to re-open after circuit breaker. The Business Times, p. 2.

Henderikx, P., \& Jansen, D. (2018). The changing pedagogical landscape: In search of patterns in policies and practices of new modes of teaching and learning. Maastricht, The Netherlands: European Association of Distance Teaching Universities (EADTU). https://eadtu.eu/documents/Publications/LLL/2018_-

_The_Changing_Pedagogical_Landscape.pdf

Hodges, C., Moore, S., Lockee, B., Trust, T., Bond, A. (March 27, 2020). The difference between emergency remote teaching and online learning. EDUCAUSE Review. 
https://er.educause.edu/articles/2020/3/the-difference-between-emergency-remote-teachingand-online-learning

Illeris, K. (1974). Problemorientering og deltagerstyring. Oplag til en alternativ didaktik. København: Munksgaard.

Janta, M. (2020). COVID-19 has caused 700,000 Australians their jobs injust a week. Australian Broadcasting Commission (ABC) News. https://www.abc.net.au/news/2020-04-21/covid-19costs-6-per-cent-of-jobs-in-3-weeks/12168670

Jayasuriya, K. (2020). Covid-19 has revealed a crisis in Australia's HE crisis. The World Higher

Education Rankings. https://www.timeshighereducation.com/blog/covid-19-has-

revealed-crisis-australian-he-governance

Johns Hopkins University School of Medicine. (2020a). Coronavirus Resource Center. https://coronavirus.jhu.edu/

Johns Hopkins University School of Medicine. (2020b). Coronavirus Resource Center: Racial data transparency. https://coronavirus.jhu.edu/data/racial-data-transparency

Johns Hopkins University School of Medicine. (2020c). Coronavirus Resource Center: COVID-19 dashboard. https://coronavirus.jhu.edu/map.html

Karanicolas, S. (2018, Nov/Dec). The importance of scaffolded learning [online]. Education Technology $\quad$ Solutions, $\quad 85, \quad 38-40 . \quad$ ISSN: https://search.informit.com.au/documentSummary;dn=093971778871689;res=IELBUS

Khadem, N. (2020). Qantas and Jetstar to stand down 20,000 workers due to Corona Virus. Australian Broadcasting Network. https://www.abc.net.au/news/2020-03-19/qantas-to-standdown-two-thirds-of-employees-due-to-coronavirus/12069876

Lange, H., \& Meier, L (Eds.). (2009). The new middle classes: Globalizing lifestyles, consumerism and environmental concern. Berlin: Springer Science+Business Media.

Lave, J. \& Wenger, E. (1991). Situated learning: Legitimate peripheral participation. Cambridge: Cambridge University Press.

Lauvås, P. \& Handal, G. (2006). Vejledning og praksisteori. Århus: Klim, 221.

Lillis, T., Harrington, K., Lea, M. R., \& Mitchell, S. (Eds.). (2015). Working with academic literacies: Case studies towards transformative practice. Fort Collins CO \& Anderson SC: WAC Clearinghouse and Parlor Press.

Lo, Y. W. W. (2017). Think global, think local: The changing landscape of higher education and the role of quality assurance in Singapore. Policy and Society, 33(3), 263-273, DOI: 10.1016/j.polsoc.2014.09.002

Mahmud, A. H. (2020, 25 March). NUS, NTU students allowed to take more modules on ungraded basis to ease COVID-19 anxiety. Channel News Asia, 
https://www.channelnewsasia.com/news/singapore/nus-ntu-students-ungraded-option-covid-

19-anxiety-12575598

Marginson, S. (2011). Higher education in East Asia and Singapore: Rise of the Confucian model. Higher education, 61(5), 587-611.

Maxwell, J. (2020). The leader's greatest return: Attracting, developing, and multiplying leaders.

New York: HarperCollins Leadership.

Ministry of Higher Education and Science, Denmark. (2020). Higher education. https://ufm.dk/en/education/higher-education

Motta, S. C., \& Bennett, A. (2018). Pedagogies of care, care-full epistemological practice and "other" caring subjectivities in enabling education. Teaching in Higher Education, 23(5), 631646.

National Institute of Allergy and Infectious Diseases. (2020). https://www.niaid.nih.gov/

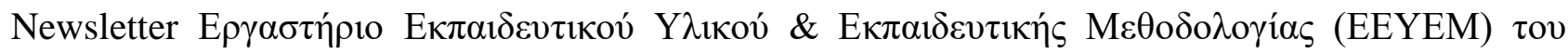

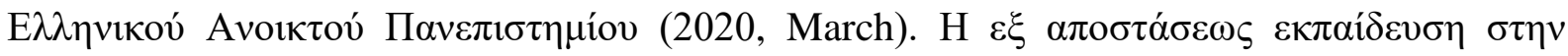

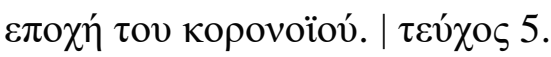

Ng, P. T., \& Tan, C. (2010). The Singapore Global Schoolhouse: An analysis of the development of the tertiary education landscape in Singapore. International Journal of

Educational Management, 24(3), 178-188. http://dx.doi.org/10.1108/09513541011031556

Norrestad, F. (2020, May 13). Number of coronavirus (COVID-19) cases in Denmark since February 2020. https://www.statista.com/statistics/1102237/coronavirus-cases-developmentin-denmark/

Nystrand, M. (1982). What writers know: The language, process, and structure of written discourse. New York: Academic.

Office for National Statistics. (2020, May 28). Coronavirus (COVID-19) Infection Survey pilot: 28 May 2020.

https://www.ons.gov.uk/peoplepopulationandcommunity/healthandsocialcare/conditionsanddi $\underline{\text { seases/bulletins/coronaviruscovid19infectionsurveypilot/28may2020 }}$

Olesen, M. N. (2011). Bildung in a new context in Danish university teaching with some remarkable results. Forum on Public Policy, 3, 1-15. https://files.eric.ed.gov/fulltext/EJ969851.pdf

Olsen, P. B. \& Pedersen, K. (1997). Problemorienteret projektarbejde: en varktøjsbog. Roskilde: Roskilde Universitetsforlag.

Pendleton-Jullian, A. (2018). In James, H. Mapping the pragmatic imagination: An interview with Ann Pendleton-Jullian. [Interview]. (p.13), Exploring Imagination in Learning, Education 
and Practice, 11A, 13 http://www.creativeacademic.uk/uploads/1/3/5/4/13542890/ cam 11a.pdf

Pendleton-Jullian, A. \& Brown, J.S. (2016). Pragmatic imagination: Single from design unbound. http://www.pragmaticimagination.com/

Pennsylvania Campus Compact. (2020). coalition/members/how-to-join/pennsylvania/

Philadelphia Higher Education Network for Neighborhood Development. (2020). http://phennd.org/ Pogner, K.-H. (2012). A social perspective on writing in the workplace: Communities of Discourse (DoC) and Communities of Practice (CoP). In Rothkegel, A. \& Ruda, S. (Eds.). Communication on and via technology. Berlin \& Boston: De Gruyter Mouton, 83-107.

Pogner, K.-H., \& Søderberg, A.-M. (2003). The discourse of all department E-mails: A case study. In Müller, A.P., \& Kieser, A. (Eds.). Communication in organizations: Structures and practices. New York: Peter Lang, 241-259.

Prime Minister of Australia. (2020). National COVID-19 Coordination Committee. [Media Release]. https://www.pm.gov.au/media/national-covid-19-coordination-commission

Public Health Services of Canada. (2020). Government of Canada takes action on COVID-19. https://www.canada.ca/en/public-health/services/diseases/2019-novel-coronavirusinfection/canadas-reponse/government-canada-takes-action-covid-19.html

QS Top Universities. (2020; accessed 2020, April 30). https://www.topuniversities.com/universityrankings/university-subject-rankings/2020/education-training

Raue, K., \& Lewis, L. (2011). Students with disabilities at degree-granting postsecondary institutions. (NCES 2011-018). U.S. Department of Education, National Center for Education Statistics. Washington, DC: U.S. Government Printing Office. https://nces.ed.gov/pubsearch/ pubsinfo.asp?pubid $=2011018$

Ritzer, G. (2004). The globalization of nothing. Thousand Oaks CA: Pine Forge Press.

Robertson, R., \& White, K.E. (2003). Globalization: An overview. In Robertson, R., White, K.E.

(Eds.). Globalization: Critical concepts in sociology. London: Routledge, 1-45.

Roudometof, V. (2015). The glocal and global studies. Globalizations 12(5), 774-787.

Royal Roads University. (2020). About Royal Roads. https://www.royalroads.ca/about-royal-roads

Sam, C. Y. (2017). Private education in Singapore. Contemporary issues and challenges. Singapore: World Scientific.

Saunders, C. (2020). COVID-19. What is Australia's National Cabinet? Law School, University of Melbourne. https://law.unimelb.edu.au/covid-19/covid-19-what-is-australias-national-cabinet Schön, D. A. (1983). The reflective practitioner. New York NY: Basic Books.

Schön, D. A. (1987): Educating the reflective practitioner. San Francisco CA: Jossey-Bass. 
Seet, B. (2020, March 17). Commentary: Why Singapore is better prepared to handle COVID-19 than SARS. Channel News Asia. https://www.channelnewsasia.com/news/commentary/ $\underline{\text { singapore-better-prepared-to-handle-COVID-19-than-sars-12535076 }}$

Selkrig, M. \& Keamy, R. K. (2017). Creative pedagogy: A case for teachers' creative learning being at the centre. Teaching Education, 28(3), 317-332

DOI:10.1080/10476210.2017.1296829

Shukaitis, S. (2018). Book review of: Sam C. Y. (2017). Private education in Singapore: Contemporary issues and challenges. Singapore: World Scientific. Journal of Applied Learning \& Teaching, 1(1), 39-40.

Sidhu, R., Ho, K. C., \& Yeoh, B. (2011). Emerging education hubs: The case of Singapore. Higher Education, 61(1), 23-40.

Siemens, G., \& Conolo, G. (2011, March). Special issue-Connectivism: Design and delivery of social networked learning. [Editorial]. International Review of Research in Open and Distance Learning 12(3), i-iv.

Singapore Ministry of Health. (2020a). Updates on COVID-19 (Coronavirus disease 2019) local situation. https://www.moh.gov.sg/COVID-19

Singapore University of Technology and Design. (2020). Education collaboration with MIT. https://www.sutd.edu.sg/About-Us/Collaborations/MIT

Skills Future Singapore. (2020). PEIs. https://www.ssg.gov.sg/cpe/peis.html

Smith H. (2020, April 14). How Greece is beating coronavirus despite a decade of debt. The Guardian. https://www.theguardian.com/world/2020/apr/14/how-greece-is-beatingcoronavirus-despite-a-decade-of-debt

Swales, J.M. (1990). Genre analysis: English in academic and research settings. Cambridge: University Press.

UNESCO. (2020). Groundwater portal. https://groundwaterportal.net/ucl accessed 29/04/2020

University College London. (2020a). History of the IOE. https://www.ucl.ac.uk/ioe/aboutioe/history-ioe

University College London. (2020b). Key statistics. https://www.ucl.ac.uk/about/what/key-statistics University College London. (2020c). Medical sciences faculty. https://www.ucl.ac.uk/medicalsciences/ 
University College London. (2020d). News. https://www.ucl.ac.uk/news/2020/apr/covid-19-uclacademics-mobilise-provide-critical-advice-and-expert-comment

University College London. (2020e). School and college partnerships. https://www.ucl.ac.uk/ioe/clients-and-partners/school-and-college-partnerships

University College London. (2020f). PGCE primary. https://www.ucl.ac.uk/ioe/courses/teachertraining/primary-pgce

University of South Australia. (2020a). About UniSA. https://www.unisa.edu.au/about-unisa/

University of South Australia. (2020b). Study law at UniSA. https://study.unisa.edu.au/law/

University of South Australia. (2020c). Aboriginal engagement. https://unisa.edu.au/aboutunisa/Aboriginal-education/

Vygotsky, L. S. (1978). Mind in society: The development of higher psychological processes. Cambridge, MA: Harvard University Press.

Waring, P. (2014). Singapore's global schoolhouse strategy: Retreat or recalibration? Studies in Higher Education, 39(5), 874-884.

Widener University. (2020a). Coronavirus information. https://www.widener.edu/coronavirus

Widener University. (2020b). About Widener. https://www.widener.edu/about

Widener University. (2020c). Civic engagement. https://www.widener.edu/about/points-pride/civicengagement

Wiepke, C. (2009). Employability in the Bologna Process: An area of tension between society, businesses and students. International Journal of Learning, 16(4), 435-445.

Wolf, T. (2020a). Order of the Governor of the Commonwealth of Pennsylvania for individuals to stay at home. https://www.governor.pa.gov/wp-content/uploads/2020/03/03.23.20-TWWCOVID-19-Stay-at-Home-Order.pdf

Wolf, T. (2020b). Amendment to the order of the Governor of the Commonwealth of Pennsylvania for individuals to stay at home. https://www.governor.pa.gov/wp-content/ uploads/2020/04/20200420-GOV-Stay-at-Home-Order-Amendment.pdf

Wolf, T. (2020c). Process to reopen Pennsylvania. https://www.governor.pa.gov/process-to-reopenpennsylvania/

World Health Organization. (2020). Rolling updates on coronavirus disease (COVID-19). https://www.who.int/emergencies/diseases/novel-coronavirus-2019/events-as-they-happen Worldometer Coronavirus (2020). https://www.worldometers.info/coronavirus/ 
Ye, R. (2016). Transnational higher education strategies into and out of Singapore:

Commodification and consecration. TRaNS: Trans-Regional and-National Studies of Southeast Asia, 4(1), 85-108. 